\title{
Monitoring of Khulans and Goitered Gazelles in the Mongolian Gobi - Po- tential and Limitations of Ground Based Line Transects
}

\author{
Petra Kaczensky ${ }^{1, *}$, Oyunsaikhan Ganbaatar ${ }^{2,3}$, Nanjid Altansukh ${ }^{2}$, Namtar Enksaikhan $^{4}$, and \\ Stephanie Kramer-Schadt ${ }^{5}$
}

${ }^{I}$ Research Institute of Wildlife Ecology, University of Veterinary Medicine, Savoyenstrasse 1, A-1160, Vienna, Austria,

${ }^{2}$ Great Gobi B Strictly Protect Area, Takhin Tal, Gobi-Altai Aimag, Mongolia

${ }^{3}$ National University of Mongolia, Factulty of Biology, Department of Zoology, Ulaanbaatar, Mongolia

${ }^{4}$ International Takhi Group, Mongolia Office, Ulaanbaatar, Mongolia

${ }^{5}$ Leibniz Institute for Zoo and Wildlife Research, Berlin, Germany

\begin{abstract}
Central Asian remote rangelands are home to several charismatic, rare and far ranging ungulates which are increasingly becoming under pressure from human encroachment. Population monitoring is challenging due to the vast expanse of the species ranges, tight budgets and limited availability of suitable fixed winged-aircraft. Consequently, many current population estimates are based on pragmatically designed ground-bound transect surveys. Although, ample literature exists on how to design surveys in an ideal world, little effort has been made to demonstrate the potential and limitations of a time-series of ground-bound transect surveys under real world constrains.

Since 2003 we have been monitoring the two sympatric steppe ungulates, Asiatic wild ass ("khulan", Equus hemionus) and goitered gazelles ("gazelle", Gazella gutturosa), in the Great Gobi B Strictly Protected Area in south-western Mongolia using ground-bound line transects. Both species showed clear species-specific seasonal variation in group sizes which seem related to birthing and mating periods. Data on annual recruitment were impeded by the long flight distances and the difficulty to reliably identify and count young of the year. Distribution of khulans and gazelles showed clear speciesspecific seasonal patterns and highlighted the importance of two oasis complexes. Population estimates of 33 surveys covering $10,383 \mathrm{~km}^{2}$ were highly variable even between consecutive surveys and had huge $95 \%$ confidence intervals (khulan: range: 1,707 to 45,040 , gazelles: range: 2,564 to 10,766 ) making them unsuitable to obtain robust baseline population estimates.

Although our individual surveys were poor measures of population abundance, they provided important data on group sizes and species distribution and are presently used for Bayesian hierarchical trend modelling and species specific habitat suitability analysis. The ground surveys are relatively inexpensive as compared to aerial surveys and thus can be conducted at short temporal intervals, engaging park staff and researchers with local people thereby helping mutual understanding, information transfer, and detection of illegal activities.
\end{abstract}

Keywords: Asiatic wild ass, Distance sampling, Equus hemionus, Gazelle subgutturosa, Goitered gazelle, Mongolia, Monitoring.

\section{INTRODUCTION}

Central Asian remote rangelands are home to several charismatic, rare and far ranging ungulates which are increasingly becoming under pressure from human encroachment (Schaller 1998, Robinson and Milner-Gulland 2003, Mallon and Zhigang 2009, Batsaikhan et al. 2014). Reliably monitoring species is a challenge due to the vast

*Address correspondence to this author at the Research Institute of Wildlife Ecology, University of Veterinary Medicine, Vienna, Savoyenstrasse 1, A1160 Vienna, Austria; Tel.: (+43) 125077 - 7181;

Fax: (+43) 125077 - 94 7181; E-mail: Petra.Kaczensky@vetmeduni.ac.at expense of the species ranges, tight budgets, and limited availability of suitable fixed winged-aircrafts (Singh and Milner-Gulland 2011). Consequently, many current population estimates are based on pragmatically designed groundbound transect surveys which in turn often provide the main source of information for species assessments, including the IUCN Red List assessment (Rodrigues et al. 2006). Although, ample literature exists on how to design strip and line transects surveys in an ideal world (e.g. Buckland et al. 2001, Sutherland 2006, Thomas et al. 2010) and how difficult it is to implement these prerequisites (e.g. Harris 1996), little effort has been made to document their potential and limitations under real world constrains using repeated surveys over multiple years. 


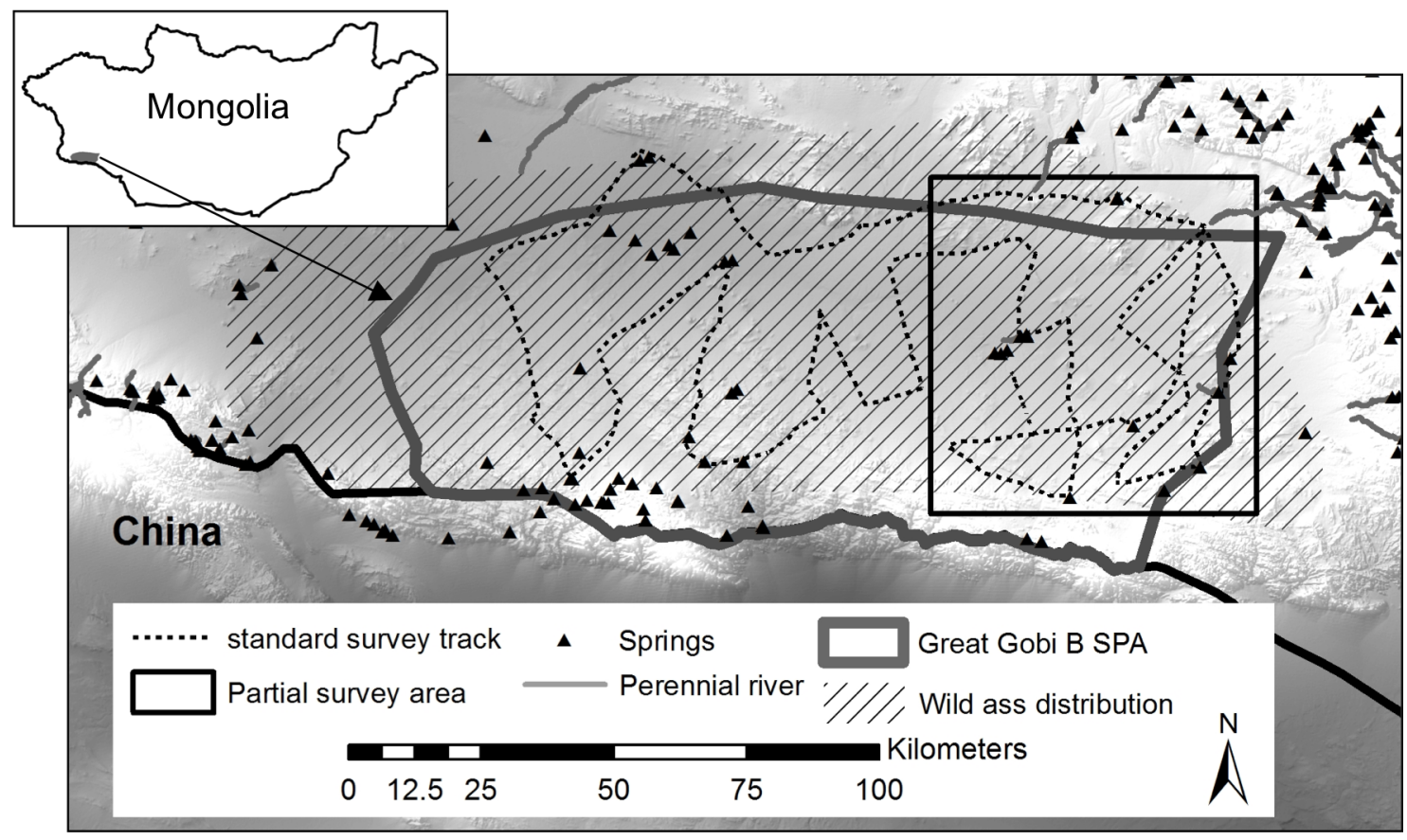

Fig. (1). Survey area for khulans and goitered gazelles in the $9,000 \mathrm{~km}^{2}$ Great Gobi B Strictly Protected Area in south-western Mongolia. Location of two key oasis complexes: $1=$ Chonin us, $2=$ Takhi us.

The Mongolian Gobi is a vast stretch of arid land that provides an important refuge for several endangered large steppe ungulates. Mongolia's change to a free market economy resulted in dramatic socioeconomic changes, also affecting the Gobi regions. Infrastructure developments, particularly associated with mining, threaten to fragment and destroy habitat (Mallon and Jiang 2009, Kaczensky et al. 2011a, Batsaikhan et al. 2014). Overstocking with livestock results in competition for and degradation of pastures (Fernandez-Gimenez 1999, Sheehy et al. 2010, Berger et al. 2013). The huge demand for wildlife products in adjacent China, the increasing gap between rich and poor, and the deterioration of old values and norms resulted in high levels of illegal hunting (Pratt et al., 2004; Wingard \& Zahler 2006). At the same time, climate change scenarios predict a raise in temperature and an increase in the occurrence of extreme weather events (IPPC 2007). Monitoring wildlife populations is increasingly becoming a priority, particularly for threatened species and in protected areas.

Two ungulate species can be found throughout the plains of the vast Gobi region of southern Mongolia, the endangered Asiatic wild ass (Equus hemionus; "khulan" in Mongolian; Moehlman et al. 2008) and the vulnerable goitered gazelle (Gazella subgutturosa; Mallon 2008). Past population estimates of khulans and goitered gazelles in Mongolia arose from attempted total counts that lacked statistical rigor (Zhirnov and Ilyinsky 1986, Lhagvasuren et al. 1999, Amgalan 2000, Feh et al. 2001, Lhagvasuren 2007), while those implying statistical methods were plagued by low precision (Reading et al. 2001, B. Lkhagvasuren and S. Strindberg, unpubl. data). A recent large scale aerial survey (NortonGriffiths et al. 2013) suggested that several past groundbound transect surveys likely both widely under- and overestimated the actual population size.
In 2003, we started monitoring goitered gazelles and khulans in the Great Gobi B Strictly Protected Area (SPA) in the south-western Gobi using ground based line transects. Our aims were to explore the potential of line transect surveys to: 1) identify group size and recruitment dynamics, 2) document seasonal patterns in species distribution, and 3) obtain baseline population estimates. We discuss our findings in the light of large-scale conservation in remote areas.

\section{Study Area}

The Dzungarian Gobi in south-western Mongolia is surrounded by high mountains on three sides. This natural geographic isolation is further enhanced by the border fence separating Mongolia from China along its southern and western edge. Almost the entire eastern and central part of the Dzungarian Gobi falls into the $9,000 \mathrm{~km}^{2}$ Great Gobi B Strictly Protected Area (SPA; Fig. 1).

Elevations within the Great Gobi B SPA range from 1,000 to $2,840 \mathrm{~m}$. Climate is continental with an average annual temperature around $1.0^{\circ} \mathrm{C}$ and temperature extremes varying from $-43^{\circ} \mathrm{C}$ in winter to $+35^{\circ} \mathrm{C}$ in summer (Appendix 1). Average annual rainfall is $96 \mathrm{~mm}$ with a peak during summer. Average snow cover lasts 97 days. Rain- and snowfall can be highly variable from year to year in space and time and the area is generally considered to follow nonequilibrium dynamics (Fernandez-Gimenez and Allen-Diaz 1999).

The landscape of the Great Gobi B SPA is dominated by plains in the east and rolling hills in the west. Open water (rivers \& springs) is unevenly distributed with almost no water in the central or western part of the park. Desert areas are widely dominated by Chenopodiaceae, such as 
Haloxylon ammodendron and Anabasis brevifolia. The steppe areas are dominated by Asteraceae, such as Artemisia and Ajania, and Poaceae like Stipa and Ptilagrostis (von Wehrden et al. 2006).

The park is used by $\sim 100$ families with $\sim 60,000$ livestock, predominantly in winter and during spring and fall migration (Kaczensky et al. 2007a). In summer, human presence in the park is almost negligible. No paved roads exist and dirt tracks are not maintained. In winter, access and mobility within the park are often limited by snow cover. Poaching occurs, but based on the small number of wild ungulate carcasses encountered, seems to be of minor importance compared to other Gobi areas (Kaczensky et al. 2006). Nevertheless, khulans and gazelles are very wary and generally start to run when they spot a vehicle.

\section{Study Species}

The wild ungulate community of the steppe areas in the Great Gobi B SPA consists of goitered gazelle (hereafter called "gazelle"), khulan, and a small population of reintroduced Przewalski's horse (Equus ferus przewalskii). The khulan population of the Dzungarian Gobi constitutes a rather closed population and is restricted to $11,983 \mathrm{~km}^{2}$ in and immediately around the Great Gobi B SPA but excluding the high mountains (Kaczensky et al. 2011a; Fig. 1).

Khulans in the Dzungarian Gobi have non-exclusive annual home ranges in the magnitude of 4500 to $7000 \mathrm{~km}^{2}$ (Kaczensky et al. 2008, Kaczensky et al. 2011a,b, Kaczensky unpubl. data). They seem to show little preference for any particular plant community type, but avoid steep slopes and need regular access to open water (Kaczensky et al. 2008, Kaczensky et al. 2010). Like other arid adapted equids, khulans seem to live in fission-fusion groups, with the only stable unit being females and their foals (Sundaresan et al. 2007, Kaczensky et al. 2008). Females give birth in mid-June to a single foal and come into estrous 1-2 weeks post-partum. Females are polyestrous with estrous recurring every 21-25 days until conception or the end of the breeding season (Asa 2011, Schook et al. 2013). Consequently, peak mating period is the end of June, but stretches well into July (Kaczensky unpubl. data).

Gazelles have been little studied in Mongolia, but likely also range over large areas. Gazelles visit water points, but seem less water dependent than khulans (Heptner et al. 1988, Nandintsetseg et al. in prep.). No studies have been conducted looking at habitat preferences in Central Asia, but in adjacent Xinjiang province, China, Stipa glareosa was a major food item throughout the year, whereas in autumn and winter Haloxylon ammodendron becomes quite important (Xu et al. 2012). Goitered gazelles usually occur in small groups, although it is possible to find larger aggregations (Heptner et al. 1988, Qiao et al. 2011, Blank et al. 2012). Fawns, often twins, are born end of May/begin of June. Rutting season is from mid-October through mid-December, during which time dominant males defend small territories (Blank 1998, Qiao et al. 2011, Xia et al. 2014).

\section{METHODS}

\section{Line Transect Surveys}

Between April 2003 and October 2010 we conducted 71 line transect surveys for khulans and gazelles. Thirty-five surveys just covered the eastern part of the Great Gobi B SPA (partial park survey), while 36 surveys covered the entire protected area (all park survey; Fig. 1, Appendix 2). Surveys were generally attempted once a month, but adverse weather conditions or technical problems on several occasions made surveys impossible or resulted in missing data.

Our surveys followed a distance sampling approach (Thomas et al. 2010) using a Russian UAZ 4x4 jeep. A survey team consisted of 4 people (driver, data recorder, 2 spotters with compasses) recruited from park rangers and the Great Gobi B SPA administration staff. Maximum speed was $40 \mathrm{~km} / \mathrm{h}$ hur and observers were seated $\sim 1.20 \mathrm{~m}$ off the ground.

For each gazelle or khulan sighting the team took a GPS fix of their own position and a compass bearing towards the location where an animal group was first detected. Observers recorded group size, composition (distinguishing when possible between adults and young of the year), and the main behaviour (laying, standing, walking or running) of the animals. Species did not occur in mixed groups and groups were generally easily distinguishable as several animals standing or running in close proximity. Initial observer distance had to be estimated because flight distances were large and conventional rangefinders are incapable of measuring distances beyond $700 \mathrm{~m}$. The survey team regularly calibrated their distance estimates using people placed at known intervals of $100,500,1000,2000,3000$ and $5000 \mathrm{~m}$. After each survey, date, time and the GPS coordinates were downloaded from the GPS unit to calculate animal location and perpendicular distances to the transect line.

The Gobi ecosystem is very sensitive and vehicles leave long lasting scars in the vegetation. Consequently, we refrained from using a random or systematic survey design, but rather made largely use of the existing dirt track system. The standard all park survey consisted of 43 transect lines varying in length between $1.5 \mathrm{~km}$ and $32 \mathrm{~km}$ and summing up to a total effort of $762 \mathrm{~km}$. The partial park survey consisted of 21 transect lines with a total effort of $350 \mathrm{~km}$. However, in reaction to track conditions and in order to exploit alternative routes, transect lines did slightly differ among surveys. Individual transects were defined when the track changed direction or when marked changes in the topography occurred. Transect lines ran though all plant community types, except the high mountain communities unused by the steppe ungulates (Fig. 1, Appendix 3).

Past and recent telemetry data of khulans in Great Gobi B SPA showed neither avoidance nor attraction of khulans to dirt roads in general or to our survey track in particular (Kaczensky et al., 2008, P. Kaczensky unpubl. data). The steppe habitat of the Great Gobi B SPA consists of open landscape without any tree cover. Telemetry data suggests that khulans use the seven main plant communities more or less as they are available (Kaczensky et al., 2008). However, no such data are available for gazelles. 
Table 1. Khulans and goitered gazelles encountered on 71 line transect surveys in Great Gobi B SPA from 2003-2010.

\begin{tabular}{|c|c|c|c|c|c|c|c|c|}
\hline \multirow{2}{*}{ Species } & \multirow{2}{*}{ N groups } & \multicolumn{6}{|c|}{ Group Size } & \multirow{2}{*}{$\begin{array}{c}\mathbf{N} \\
\text { Individuals }\end{array}$} \\
\hline & & Mean & SD & Median & Mode & Min. & Max. & \\
\hline Gazelle & 3,778 & 5.83 & 7.85 & 3 & 1 & 1 & 111 & 22,029 \\
\hline Khulan & 2,197 & 32.50 & 108.91 & 5 & 1 & 1 & 2,110 & 71,405 \\
\hline
\end{tabular}

\section{Data Analysis}

\section{Annual Group Size Variation}

Since we did not find significant differences in logtransformed group sizes of gazelles (Mann-Whitney U-test, $P=0.260)$ and khulans $(P=0.975)$ between partial and all park surveys we pooled data from all 71 surveys. To test for significant non-linear effects of the respective month on logtransformed group sizes for khulans and gazelles we used generalized additive models (GAM; Hastie and Tibshirani 1990) using program $\mathrm{R} 2.10 .1$ (R Development Core Team 2009). We assessed whether there were random effects of the respective sampling year by comparing nested models using a likelihood ratio test (LRT). To this end, we fitted a fixed effects model by generalized least squares (GLS) and a mixed effects model (GLMM) containing sampling year as random intercept (package nlme) following Zuur et al. (2009). All models were estimated with restricted maximum likelihood (REML). Non-linearity, if revealed in the GAM, was considered by including month as appropriate $\mathrm{x}^{\text {th }}$ order polynomial based on model selection with the lowest AIC (Johnson and Omland 2004). We calculated the $p$-values based on the likelihood ratio using the correction provided by Verbeke and Molenberghs (2000; in Zuur et al. 2009) for comparing models without random effects versus models with random intercept.

\section{Seasonal Spatial Distribution}

We analysed the seasonal spatial distribution of khulans and gazelles for the 33 all park surveys using the "Euclidian allocation" of area to the survey transects and "ordinary kriging (interpolation technique in which the surrounding measured values are weighted to derive a predicted value for an unmeasured location)" function in ArcMap 9.3 (ESRI, Environmental Systems Research Institute, Inc., Redlands, California, USA) based on mean densities over all surveys during this season. We defined the four seasons: spring (MarchMay), summer (June-August), fall (September-November), and winter (December-February) based on average annual weather conditions (Appendix 1).

\section{Abundance Estimates}

We calculated abundance estimates using program DISTANCE 6.0.2 (Research Unit for Wildlife Population Assessment, University of St. Andrews, UK; http:/www.ruwpa.st-and.ac.uk/distance/) only for the 33 all park surveys, but included sighting distances of the first 24 partial park surveys for calculation of the probability detection function. We used the conventional distance sampling option with $500 \mathrm{~m}$ bins up to a maximum distance of $3000 \mathrm{~m}$. We used a half normal cosine probability detection function based on all 57 surveys available in distance format. We used post-stratification for stratum (in our case the individual survey) to get separate cluster size and density estimates by stratum. We tested for a size bias in the detection $\mathrm{g}(\mathrm{x})$ of different sizes of groups (clusters) of animals. When the size bias regression was significant at $P=0.15$ then we used the regression $\ln$ (cluster size) against the estimated $\mathrm{g}(\mathrm{x})$, else the mean cluster size.

We calculated our survey area based on a square around the outer edges of the 3,000 m buffer around our standard survey track. The resulting survey area was $10,383 \mathrm{~km}^{2}$ for the all park survey, thus covering $86 \%$ of the total distribution area of khulans in the Dzungarian Gobi, but $14 \%$ more area than the $9,000 \mathrm{~km}^{2}$ Great Gobi B SPA (Fig. 1).

\section{RESULTS}

\section{Annual Group Size Variation}

We encountered 2,197 groups of khulans and 3,778 groups of gazelles (Table 1). Group sizes showed significant non-linear effects throughout the year (month; GAM, df $=1$, $\left.\mathrm{F}_{\text {khulan }}=45.8, \mathrm{~F}_{\text {gazelle }}=153.7, p<0.001\right)$. The khulan data were best described by including month as quadratic term in the GLMM and gazelle data were best described by a $5^{\text {th }}$ order polynomial resulting in a bimodal group size distribution throughout the year. The respective sampling year had significant effects for khulans (LRT, df $=1$, loglikelihood ratio $=6.96, p=0.0042)$ and gazelles (LRT, $\mathrm{df}=1$, loglikelihood ratio $=50.0, p<0.0001)$. Khulans had the smallest group sizes in June and July, whereas gazelles showed a bimodal pattern with a low in June and an additional drop in December (Fig. 2).

We encountered very large groups of khulans (>500) 16 times: 13 in summer, 2 in fall and 1 in spring. The largest group numbered 2,110 individuals. Large groups of gazelles $(>50)$ were observed 12 times: 5 in spring and 2 each in fall and winter. The largest group numbered 111 individuals (Appendix 4).

The majority of gazelles (71\%) and khulans (57\%) were observed running (Appendix 5). Due to the large flight distances and the swift flight response of the majority of khulans and gazelles, it was not possible to reliably determine group composition. When reasonably close, a reliable distinction between young of the year and adults was only possible until October. Young of the year for both gazelle and 

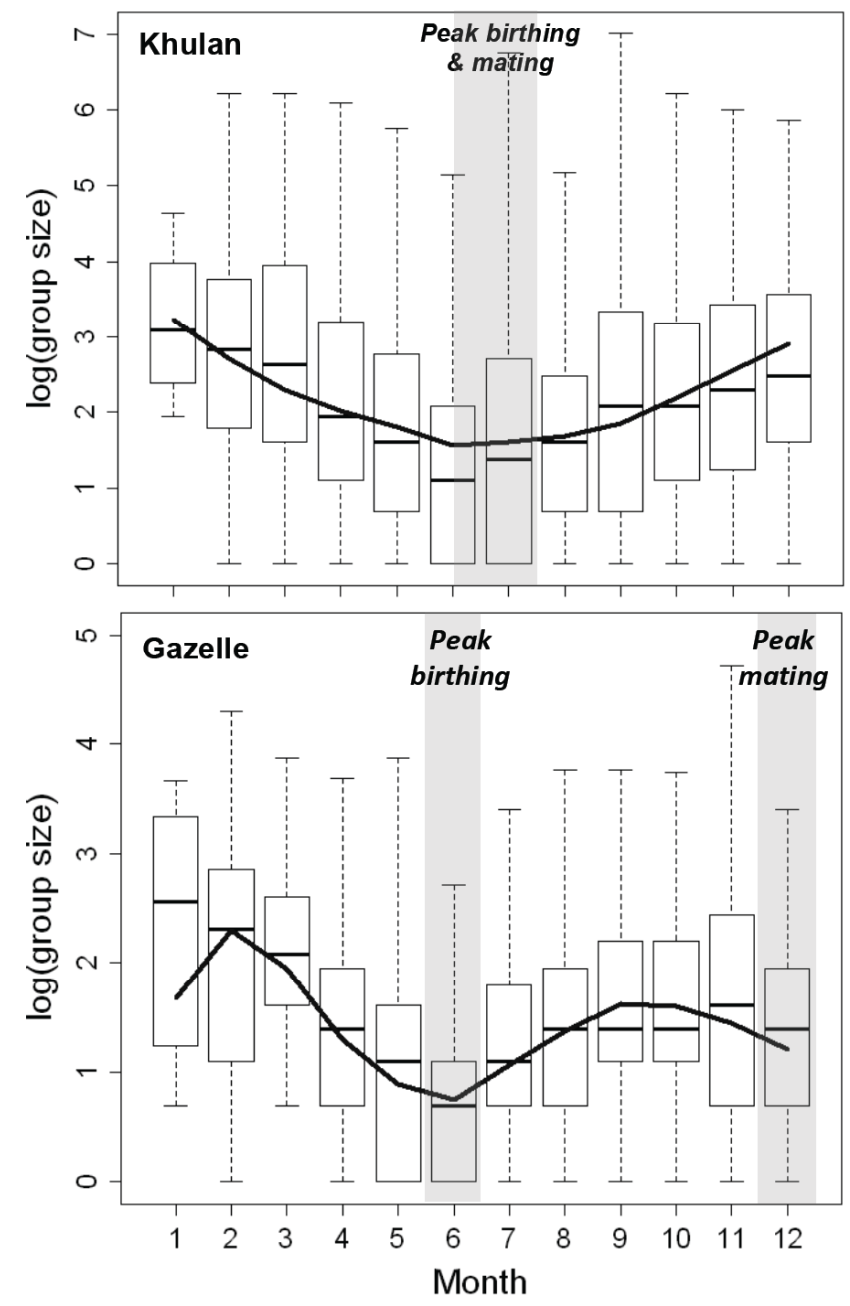

Fig. (2). Boxplots showing the median group sizes (logarithmic scale) of khulan and goitered gazelle groups by month. The trend lines show group sizes based on the values derived from the GLMMs.

khulan were first observed in June. Young of the year in groups containing foals or fawns averaged $21 \%$ in khulans and 34\% in gazelles (Appendix 6).

\section{Seasonal Spatial Distribution}

Both species showed a clear seasonal pattern in their longitudinal, but not in their latitudinal distribution. Khulans were more likely seen in the western part in spring, the central and eastern part in summer and the central parts in fall and winter. Gazelles were more likely seen in the western part of the park in fall and winter and in the eastern part of the park in spring and summer (Fig. 3, Appendix 7).

\section{Abundance Estimates}

The probability detection functions for khulan and gazelle observations were rather steep, with an effective strip width (ESW) of $673 \mathrm{~m}$ for khulans and $468 \mathrm{~m}$ for gazelles (Appendix 8). Population estimates for khulans ranged from 1,707 to 45,040 animals; had huge $95 \%$ confidence intervals and an average percentage coefficient of variance $(\% \mathrm{CV})$ of 50. Population estimates for gazelles were less variable, but still ranged from 2,564 to 10,766 animals, with large 95\% confidence intervals and an average \%CV of 29 (Fig. 4, Appendix 2). Population estimates varied hugely even between consecutive surveys and often in a magnitude well beyond recruitment potential. There seemed to be no obvious trend in population estimates over time.

\section{DISCUSSION}

\section{Annual Group Size Variation}

Long term changes in group sizes, dynamics or distribution can be important indices of population status and will also influence abundance estimates (McConville et al. 2009). So far we have no indication of any linear trend of group size dynamics over the last eight years (S. Kramer-Schadt unpubl. analysis). Furthermore, khulan group size pattern is very much in line of observations from 1992-1996 (Feh et al. 2001). However, the effect of changes in overall density on group size distribution may also be a rather small (Blank et al. 2012) or complicated by variable effects on the two sexes (Vander Wal et al. 2013) and should not be used in isolation as an indicator of population trends. Maximum group sizes may provide some additional clues and at least for khulans can provide minimum population numbers, e.g. in summer 2009 at least 2,110 khulans were present in the Great Gobi B SPA.

Both species showed clear seasonal variation in group sizes in relation to their birthing and mating season. The pattern for gazelles was largely in accordance with data from other parts of Central Asia (Heptner et al. 1988, Qiao et al., 2011, Blank et al. 2012). For khulans little data on group size distribution had previously been available. Being postpartum estrous, birthing and mating season in khulans is closely connected and peaks from mid-June to mid-July. Contrary to gazelles, khulan mares with young foals seemed to congregate with other mares with foals (Kaczensky own obs.). Nevertheless, group sizes were smallest in June/July, which may be due to subadult and barren females only forming small groups and a large portion of khulan stallions holding temporary territories (Kaczensky et al. in prep., Sundaresan et al. 2007). However, summer was also the time when large aggregations of khulans were most likely encountered.

The segregation of females with and without foals makes measuring annual reproductive success challenging as counts of a few herds may be highly skewed, depending on what groups are encountered (e.g. Enkhbileg et al. 2007, Tsendjav and Purevsuren 2007). The large flight distances in the Great Gobi B SPA make spotting and counting young of the year a real challenge and rangers were often unable to determine if and how many young of the year were present; consequently we were not able to calculate annual foal or fawn rates. The proportion of young of the year within identifiable reproductive groups may be an indicator of annual reproductive success in gazelles as one can expect more twins to be born and surviving in good years, but this assumption needs further investigation. Our monitoring data suggests annual fluctuations, 


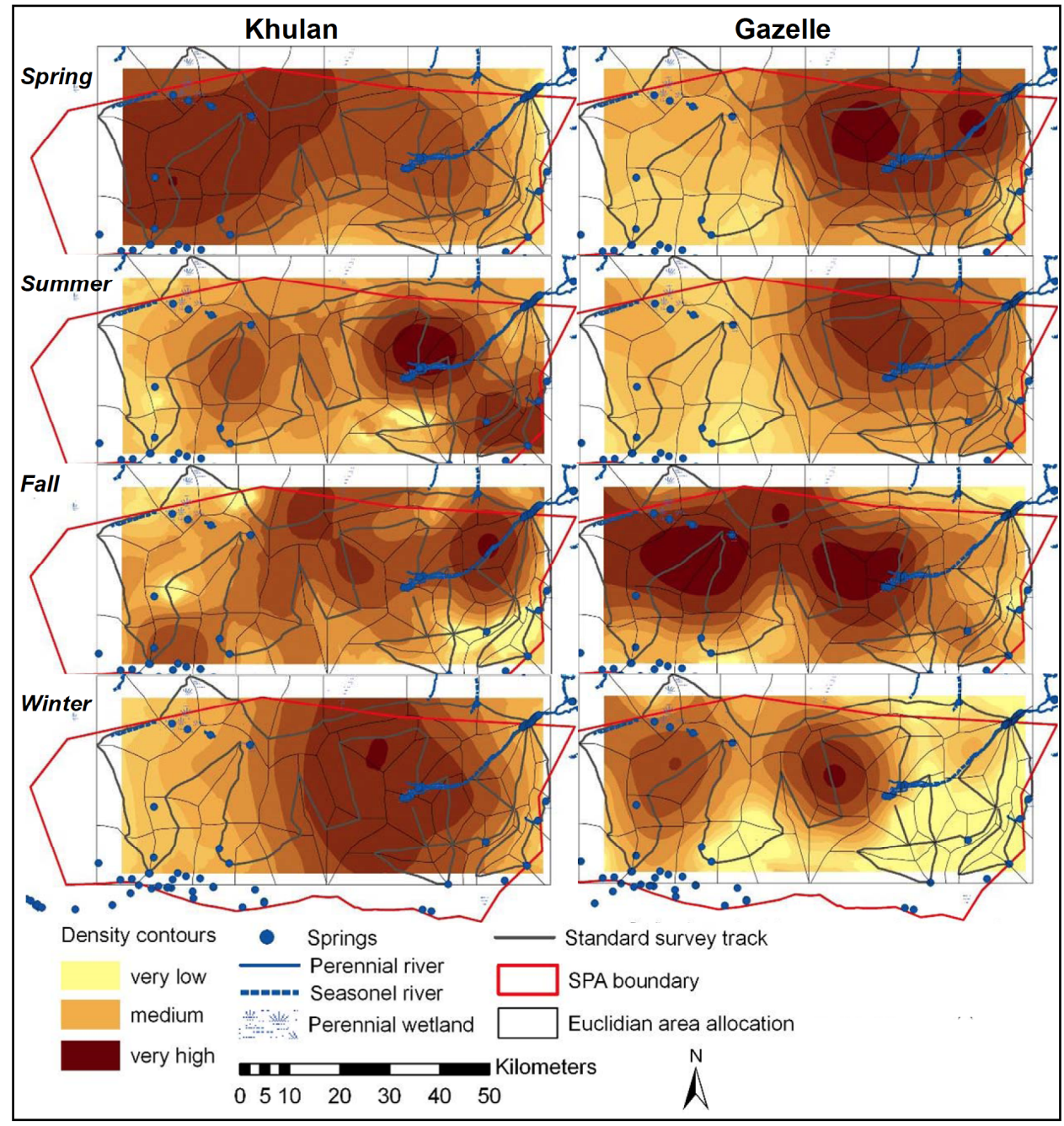

Fig. (3). Seasonal distribution of khulans and goitered gazelles based on Euclidian allocation to the survey transects and ordinary krigging of mean densities over all surveys during each season $(2004$ to 2010 : spring $=7$, summer $=12$, fall $=8$, winter $=6$ ).

but no overall trend. For khulans which can only produce one foal and where mares with foals join peers, the foal rates within reproductive groups appears to be a questionable indicator of relative annual reproductive success.

\section{Seasonal Spatial Distribution}

The most important data for park management and wildlife conservation came from the seasonal distribution data. The data clearly showed that both gazelles and khulans seasonally shift range use. The data also highlighted the importance of the two oasis complexes Takhi us in the east and Chonin us in the north-central part of the SPA for steppe ungulate conservation. Since both areas are also important Przewalski's horse habitat, ranger emergency stations have been erected in 2011 and the two oasis complexes have become focal areas for ranger patrols to discourage illegal hunting, illegal collection of Haloxylon ammodendron for fire wood, and illegal placer mining. In the past, conservation work was mostly focused on the reintroduction of the Przewalski's horse in the north-eastern corner of the SPA (Kaczensky et al. 2007a,b). The introduction of the all park surveys guaranteed the regular presence of the rangers throughout the park. This did not only allow for a better un- derstanding of wildlife and livestock distribution, but also of human activities in the Great Gobi B SPA. Regular and direct contacts with local herders and military posts throughout the park have helped mutual understanding, information transfer, and more rapid detection of illegal activities.

\section{Abundance Estimates}

Ground bound abundance estimates are challenging in the vast expanse of the study area. We violated three of the distance assumptions: random placement of the survey track, no movement of the animals prior to detection, and precise measurements of distances (Thomas et al. 2010). We had hoped to overcome some of the limitations through repeated surveys and by studying habitat- and space use in khulans (Kaczensky et al. 2008, 2011a). However, rather than narrowing down annual population estimates, our repeated surveys highlighted the low precision and poor accuracy of our population estimates. Results like these are difficult to publish, but we feel that it is actually extremely important to document and communicate such real world results to managers and conservationists. Most ground-bound surveys, particularly in remote regions of Central Asia where ungulate populations occur at low densities over large ranges, violate 


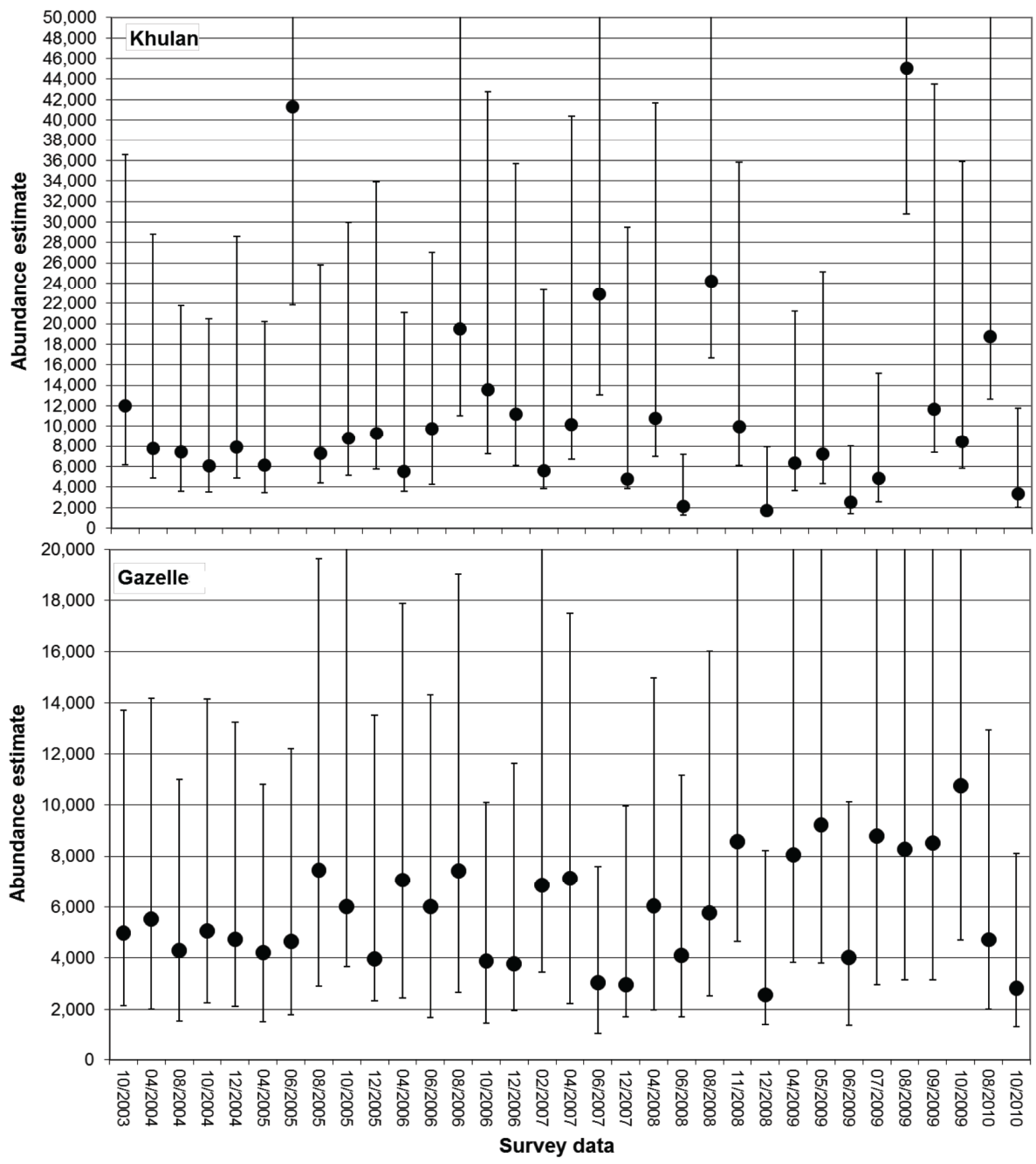

Fig. (4). Abundance estimates for khulans and goitered gazelles based on 33 all park surveys with 95\% CI.

at least some of the line transect requirements. However, ground-bound line transects are often the only available option (e.g. Bårdsen et al. 2006) and these population estimates are widely used for population assessments, particularly when they seem "reasonable" or when two repeated surveys come up with similar numbers. However, our time series data shows that this can be highly subjective and potentially wrong.

The low precision of our estimates results from the low population density, the clumped distribution and the high variability in group sizes, especially in khulans. Single surveys, conducted at annual or multi-annual intervals would have a very low probability of reliably detecting a population change (Durant et al. 2011). However, what was more disturbing, and would have remained undetected with just a single survey, was the poor accuracy of our estimates. The large fluctuations in population estimates between consecutive surveys and surveys within the same year of the more or less closed khulan population (Kaczensky et al. 2011a) are clearly artefacts and even for the lesser studied gazelles seem unlikely to be based on real abundance changes. The variation in the point estimates were so huge, that calculating pooled estimates did not seem appropriate, as we are obviously dealing with some type of unaccounted for error.
Getting to the nature of this error is far from simple as observations per survey were rather small but potential influencing factors were numerous. We believe that non-random placement of the survey track was a minor problem as radiotracking data suggests random use of habitat types at least for khulans (Kaczensky et al. 2008, P. Kaczensky unpubl. data). However, movement of the animals prior to detection frequently occurred as the majority of khulans and gazelles were detected running. Even when the animals were detected the moment the flight behaviour was initiated, the long observer distances made it impossible to use range finders, necessitating visual distance estimates. The long flight distances also forced observers to look far ahead of the transect line, which likely explains the heaping around zero ("guarding the line"; see Appendix 8). The heaping around zero results in inflated population estimates if using the actual perpendicular distances. We correct for this effect by grouping distances in rather wide bins of $500 \mathrm{~m}$. However, if and how to bin the data results in widely differing population estimates and introduces another factor of uncertainty. Furthermore, survey team composition, season, weather condition, time of the day, and travel speed also varied in changing combinations within and among surveys.

The occurrence of very large groups in khulans is also problematic. A large group reduces the overall number of 
khulan groups, thus resulting in low and/or uneven encounter rates and increases variability in group sizes. Both variables negatively affect precision. Accuracy can also be affected, as missing a large group will likely result in underestimating the population. On the other end of the spectrum population estimates will likely be inflated when members of a large herd are encountered more than once (e.g. the group is counted twice, the group splits up and a subgroup is counted again, the group disintegrates and spreads out while the survey is ongoing).

Given the abovementioned constrains, we initiated a simultaneous count point in 2010 , which produced rather robust estimates of 5,671 $(95 \% \mathrm{CI}=3,611-8,907)$ wild asses and 5,909 (95\% CI = 3762-9279) gazelles (Kaczensky et al. 2012, Ransom et al. 2012). The advantage of the simultaneous point count over the ground transects was that once the survey teams were stationed at their elevated vantage points, there was little further disturbance even allowing for multiple repeats. Consequently, only a small minority of animals was running and thus could be counted more precisely, from a better angle and with an inexpensive range finder (Ransom 2011). Furthermore, the point survey simultaneously covered half the study area, minimizing the risk of double counts. The down side of the point count is that the logistical effort and overall costs are much higher than for the ground transects (Kaczensky et al. 2012).

\section{Future Prospects}

To account for imperfect detections, line transect sampling has recently been coupled with Bayesian hierarchical modelling for analysing trends in animal abundance (Kéry et al. 2009, Moore and Barlow 2011). Since this approach allows including data uncertainty at all levels, it may be a useful tool to explore our data for trend analysis in khulan and gazelle abundance (Heckmann et al. in prep.). Furthermore, distribution data can be linked to habitat variables to develop habitat suitability models which in turn will help predict gazelle and khulan presence as well as identify seasonally important habitat features (Nandintsetseg et al. in prep.).

Although our individual surveys were poor measures of population abundance, they provided important baseline data on group sizes and species distribution and have potential for further analysis. The ground surveys are relatively inexpensive and thus can be conducted at short temporal intervals, allowing park staff and researchers to qualitatively assess environmental conditions throughout the SPA and engage with local people. We thus strongly recommend to continue the line transect surveys and back them up with point counts at 3-5 year intervals.

\section{CONFLICT OF INTEREST}

The authors confirm that this article content has no conflict of interest.

\section{ACKNOWLEDGEMENTS}

This research was conducted within the framework of the Przewalski's horse re-introduction project of the International Takhi Group, in cooperation with the Mongolian Ministry of Nature and Environment and the National University of Mongolia. Funding was provided by the Austrian Science Foundation (FWF project P14992 and P18624). We are grateful to all rangers and SPA staff for their many, many hours of dedicated work in the field, without them this work would not have been possible. Jason Ransom, Mike NortonGriffiths and Joseph Ogutu provided valuable comments and corrections on an earlier version of this manuscript.

Appendix 1. Average monthly temperatures based on hourly measurements (HOBO temperature logger, Hoskin Scientific Limited, Vancouver, Canada) at Takhin Tal research station at the NE edge of the Great Gobi B SPA in south-western Mongolia.

\begin{tabular}{|c|c|c|c|c|c|c|c|c|c|c|}
\hline Season & Month & $2003 / 4$ & $2004 / 5$ & $2005 / 6$ & $2006 / 7$ & $2007 / 8$ & $2008 / 9$ & $2009 / 10$ & 2010/11 & Mean \\
\hline \multirow[t]{2}{*}{ Spring } & 4 & 14 & 6 & 5 & 3 & 6 & 4 & 8 & -3 & 5 \\
\hline & 5 & 10 & 12 & 11 & 10 & 12 & 13 & 11 & 9 & 11 \\
\hline \multirow{2}{*}{ Summer } & 6 & 19 & 17 & 16 & 17 & 17 & 19 & 15 & 18 & 17 \\
\hline & 8 & 15 & 16 & 17 & 18 & 17 & 18 & 16 & 17 & 17 \\
\hline \multirow{3}{*}{ Fall } & 9 & 11 & 9 & 11 & 11 & 12 & 11 & 11 & 12 & 11 \\
\hline & 10 & 2 & 1 & 2 & 3 & 0 & 3 & 3 & 3 & 2 \\
\hline & 11 & -12 & -10 & -9 & -5 & -6 & -9 & -13 & -8 & -9 \\
\hline \multicolumn{2}{|c|}{ Annual max. } & 31 & 35 & 32 & 35 & 33 & 32 & 31 & 34 & \\
\hline \multicolumn{2}{|c|}{ Annual min. } & -37 & -37 & -44 & -36 & -33 & -38 & -41 & -42 & \\
\hline \multicolumn{2}{|c|}{ Annual mean } & na & 1 & 1 & 1 & 3 & 2 & 1 & 0 & \\
\hline
\end{tabular}


100 The Open Ecology Journal, 2015, Volume 8

Appendix 2. Line transect surveys for khulans and goitered gazelles in Great Gobi B SPA in south-western Mongolia between 2003-2010. [grey = all park surveys]

\begin{tabular}{|c|c|c|c|c|c|c|c|c|c|c|c|c|c|c|c|c|c|c|}
\hline \multirow{3}{*}{$\begin{array}{l}\# \\
1\end{array}$} & \multicolumn{2}{|c|}{ Date } & \multirow{3}{*}{$\begin{array}{c}\begin{array}{c}\text { Total effort } \\
\text { (in km) }\end{array} \\
406\end{array}$} & \multicolumn{2}{|c|}{ Groups encountered } & \multicolumn{2}{|c|}{ Total number seen } & \multicolumn{5}{|c|}{ DISTANCE estimate khulan } & \multicolumn{5}{|c|}{ DISTANCE estimate gazelle } & \multirow{3}{*}{ Comments } \\
\hline & \multirow{2}{*}{$\begin{array}{c}\text { from } \\
30.04 .2003\end{array}$} & \multirow{2}{*}{$\begin{array}{c}\text { to } \\
01.05 .2003\end{array}$} & & \multirow{2}{*}{$\begin{array}{c}\text { khulan } \\
23\end{array}$} & \multirow{2}{*}{$\begin{array}{c}\text { gazelle } \\
80\end{array}$} & \multirow{2}{*}{$\begin{array}{c}\text { khulan } \\
220\end{array}$} & \multirow{2}{*}{$\begin{array}{c}\text { gazelle } \\
508\end{array}$} & \multirow{2}{*}{ 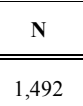 } & \multirow{2}{*}{$\begin{array}{l}\text { \%CV } \\
69.17\end{array}$} & \multirow{2}{*}{ 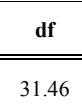 } & \multicolumn{2}{|c|}{$95 \% \mathrm{CI}$} & \multirow{2}{*}{$\frac{\mathbf{N}}{24,946}$} & \multirow{2}{*}{$\begin{array}{l}\% \mathbf{C V} \\
23.58\end{array}$} & \multirow{2}{*}{ 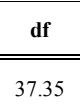 } & \multicolumn{2}{|c|}{$95 \% \mathrm{CI}$} & \\
\hline & & & & & & & & & & & 417 & 5,337 & & & & 3087 & 7923 & \\
\hline 2 & 26.05 .2003 & 27.05 .2003 & 343 & 10 & 78 & 31 & 246 & 205 & 42.13 & 27.87 & 89 & 469 & 2,981 & 28.46 & 33.6 & 1690 & 5257 & \\
\hline 3 & 31.05 .2003 & 01.06 .2003 & 381 & 30 & 60 & 130 & 172 & 571 & 51.21 & 31.76 & 214 & 1,526 & 1,501 & 28.96 & 33.11 & 843 & 2674 & \\
\hline 4 & 01.07 .2003 & 02.07 .2003 & 382 & 87 & 75 & 2693 & 287 & 6,992 & 36.06 & 68.58 & 3,481 & 14,047 & 2,670 & 19.1 & 43.07 & 1823 & 3911 & \\
\hline 5 & 06.07 .2003 & 08.07 .2003 & 343 & 55 & 39 & 3299 & 239 & 10,284 & 46.74 & 73.23 & 4,241 & 24,938 & 2,037 & 25.86 & 40.21 & 1218 & 3406 & \\
\hline 6 & 05.08 .2003 & 06.08 .2003 & 373 & 40 & 48 & 995 & 270 & 7,368 & 52.39 & 57.39 & 2,749 & 19,750 & 3,010 & 25.34 & 32.17 & 1811 & 5003 & \\
\hline 7 & 06.09.2003 & 08.09 .2003 & 382 & 10 & 29 & 65 & 195 & 297 & 65.48 & 16.78 & 84 & 1,047 & 1,846 & 38.56 & 29.71 & 863 & 3951 & \\
\hline 8 & 06.10 .2003 & 07.10 .2003 & 388 & 9 & 9 & 289 & 41 & 1,025 & 95.78 & 11.37 & 175 & 6,012 & 440 & 50.86 & 28.86 & 165 & 1173 & \\
\hline 9 & 20.10 .2003 & 24.10 .2003 & 692 & 49 & 60 & 1081 & 400 & 12,020 & 37.11 & 79.65 & 5,881 & 24,567 & 4,982 & 28.67 & 60.59 & 2840 & 8739 & \\
\hline 10 & 24.03 .2004 & 25.03 .2004 & 357 & 1 & 11 & 1 & 145 & 8 & 101.11 & 21.04 & 1 & 46 & 1,690 & 59.04 & 30.61 & 554 & 5158 & \\
\hline 11 & 15.04 .2004 & 18.04 .2004 & 996 & 40 & 88 & 2109 & 539 & 7,780 & 53.06 & 74.83 & 2,884 & 20,987 & 5,529 & 22.92 & 92.43 & 3528 & 8666 & \\
\hline 12 & 16.05 .2004 & 17.05 .2004 & 357 & 48 & 90 & 520 & 305 & 4,165 & 52.05 & 28.12 & 1,528 & 11,353 & 2,817 & 23.1 & 28.48 & 1767 & 4493 & \\
\hline 13 & 07.06 .2004 & 08.06 .2004 & 382 & 47 & 58 & 823 & 168 & 4,699 & 42.46 & 61.23 & 2,082 & 10,607 & 1,264 & 20.59 & 39.87 & 838 & 1909 & \\
\hline 14 & 05.07.2004 & 06.07 .2004 & 382 & 31 & 65 & 898 & 293 & 6,806 & 57.16 & 48.93 & 2,338 & 19,812 & 2,514 & 26.55 & 40.09 & 1483 & 4260 & \\
\hline 15 & 08.08 .2004 & 12.08.2004 & 731 & 70 & 78 & 909 & 327 & 7,419 & 34.32 & 97.8 & 3,826 & 14,388 & 4,290 & 22.61 & 61.78 & 2745 & 6703 & \\
\hline 16 & 05.09.2004 & 07.09 .2004 & 422 & 53 & 43 & 2230 & 265 & 15,103 & 51.51 & 74.52 & 5,745 & 39,701 & 2,613 & 26.17 & 37.14 & 1551 & 4401 & \\
\hline 17 & 15.10 .2004 & 20.10 .2004 & 715 & 37 & 67 & 1668 & 463 & 6,080 & 45.47 & 70.44 & 2,561 & 14,434 & 5,065 & 29.95 & 58.09 & 2817 & 9106 & \\
\hline 18 & 12.11 .2004 & 16.11 .2004 & 386 & 8 & 2 & 132 & 5 & 990 & 75.8 & 14.4 & 234 & 4,183 & 54 & 73.89 & 22.54 & 14 & 211 & \\
\hline 19 & 10.12 .2004 & 14.12 .2004 & 772 & 22 & 67 & 797 & 329 & 7,913 & 50.71 & 49.01 & 3,026 & 20,692 & 4,731 & 29.97 & 50.74 & 2625 & 8524 & \\
\hline 20 & 19.03.2005 & 21.03 .2005 & 395 & 19 & 9 & 2132 & 174 & 15,642 & 59.54 & 35.5 & 5,116 & 47,827 & 1,394 & 14.72 & 24.24 & 236 & 8227 & \\
\hline 21 & 27.04.2005 & 30.04 .2005 & 754 & 38 & 88 & 598 & 430 & 6,120 & 43.8 & 79.75 & 2,659 & 14,087 & 4,217 & 22.63 & 65.88 & 2699 & 6588 & \\
\hline 22 & 20.05 .2005 & 21.05 .2005 & 426 & 29 & 40 & 306 & 113 & 1,857 & 40.46 & 52.86 & 850 & 4,055 & 1,104 & 21.88 & 64.96 & 717 & 1701 & \\
\hline 23 & 09.06 .2005 & 13.06 .2005 & 701 & 126 & 101 & 3754 & 296 & 41,320 & 39.56 & 162.99 & 19,459 & 87,740 & 4,652 & 24.85 & 108.67 & 2864 & 7556 & \\
\hline 24 & 25.07.2005 & 27.07.2005 & 382 & 25 & 44 & 286 & 228 & 2,168 & 42.11 & 43.47 & 960 & 4,896 & 2,484 & 31.59 & 39.11 & 1332 & 4635 & \\
\hline 25 & 20.08 .2005 & 24.08 .2005 & 806 & 54 & 78 & 765 & 542 & 7,325 & 49.16 & 93.06 & 2,908 & 18,450 & 7,460 & 24.97 & 73.51 & 4569 & 12178 & \\
\hline 26 & 22.09 .2005 & 23.09 .2005 & 349 & 3 & 11 & 3 & 95 & 25 & 53.33 & 21.14 & 9 & 70 & 1,133 & 50.17 & 30.26 & 431 & 2982 & \\
\hline 27 & 17.10 .2005 & 20.10 .2005 & 818 & 42 & 40 & 1077 & 443 & 8,808 & 46.3 & 80.8 & 3,665 & 21,168 & 6,010 & 49.79 & 52.98 & 2338 & 15444 & \\
\hline
\end{tabular}


Appendix 2. contd.

\begin{tabular}{|c|c|c|c|c|c|c|c|c|c|c|c|c|c|c|c|c|c|c|}
\hline \multirow{3}{*}{$\begin{array}{l}\# \\
\end{array}$} & \multicolumn{2}{|c|}{ Date } & \multirow{3}{*}{$\begin{array}{c}\begin{array}{c}\text { Total effort } \\
\text { (in km) }\end{array} \\
349\end{array}$} & \multicolumn{2}{|c|}{ Groups encountered } & \multicolumn{2}{|c|}{ Total number seen } & \multicolumn{5}{|c|}{ DISTANCE estimate khulan } & \multicolumn{5}{|c|}{ DISTANCE estimate gazelle } & \multirow{3}{*}{ Comments } \\
\hline & \multirow{2}{*}{$\begin{array}{c}\text { from } \\
21.11 .2005\end{array}$} & \multirow{2}{*}{$\begin{array}{c}\text { to } \\
23.11 .2005\end{array}$} & & \multirow{2}{*}{$\frac{\text { khulan }}{16}$} & \multirow[t]{2}{*}{ gazelle } & \multirow{2}{*}{$\begin{array}{c}\text { khulan } \\
852\end{array}$} & \multirow[t]{2}{*}{ gazelle } & \multirow{2}{*}{$\frac{\mathbf{N}}{7,060}$} & \multirow{2}{*}{ \%CV } & \multirow{2}{*}{$\begin{array}{c}\text { df } \\
31.99\end{array}$} & \multicolumn{2}{|c|}{$95 \%$ CI } & \multirow{2}{*}{$\begin{array}{l}\mathbf{N} \\
0\end{array}$} & \multirow[t]{2}{*}{$\% \mathrm{CV}$} & \multirow[t]{2}{*}{ df } & \multicolumn{2}{|c|}{$95 \% \mathrm{CI}$} & \\
\hline & & & & & & & & & & & 2,210 & 22,549 & & & & & & \\
\hline 29 & 19.12.2005 & 23.12 .2005 & 628 & 14 & 45 & 752 & 225 & 9,251 & 50.96 & 31.44 & 3,474 & 24,632 & 3,979 & 45.52 & 38.99 & 1654 & 9571 & \\
\hline 30 & 03.01 .2006 & 05.01 .2006 & 357 & 3 & & 113 & & 916 & 82.45 & 21.81 & 206 & 4,081 & 0 & & & & & \\
\hline 31 & 20.03.2006 & 22.03.2006 & 367 & 6 & 32 & 426 & 495 & 3,363 & 65.92 & 18.69 & 955 & 11,842 & 5,617 & 40.02 & 32.33 & 2563 & 12313 & \\
\hline 32 & 26.04.2006 & 29.04.2006 & 733 & 35 & 117 & 626 & 548 & 5,555 & 55.05 & 61.16 & 1,986 & 15,542 & 7,062 & 21.5 & 56.52 & 4614 & 10809 & \\
\hline 33 & 16.05 .2006 & 17.05.2006 & 357 & 2 & 50 & 4 & 223 & 32 & 85.1 & 7.17 & 6 & 184 & 2,598 & 28.48 & 32.55 & 1471 & 4586 & \\
\hline 34 & 16.06 .2006 & 18.06.2006 & 734 & 173 & 182 & 1567 & 479 & 9,722 & 29.35 & 58.16 & 5,469 & 17,283 & 6,001 & 16.44 & 57.43 & 4327 & 8320 & \\
\hline 35 & 17.07.2006 & 21.07 .2006 & 395 & 43 & 46 & 2967 & 177 & 21,756 & 45.41 & 51.94 & 9,124 & 51,875 & 1,638 & 28.02 & 27.79 & 932 & 2877 & \\
\hline 36 & 12.08 .2006 & 14.08.2006 & 755 & 60 & 99 & 1909 & 506 & 19,526 & 43.55 & 99.72 & 8,541 & 44,639 & 7,440 & 22.57 & 68.2 & 4769 & 11607 & \\
\hline 37 & 27.09.2006 & 28.09 .2006 & 356 & 15 & 27 & 614 & 152 & 4,994 & 58.63 & 26.13 & 1,634 & 15,261 & 1,777 & 38.42 & 45.43 & 842 & 3751 & \\
\hline 38 & 22.10 .2006 & 27.10 .2006 & 741 & 41 & 54 & 1305 & 259 & 13,593 & 39.78 & 68.5 & 6,326 & 29,205 & 3,878 & 24.06 & 68.27 & 2416 & 6225 & \\
\hline 39 & 28.11 .2006 & 29.11 .2006 & $\sim 350$ & 4 & 23 & 29 & 178 & & & & & & & & & & & $\begin{array}{l}\text { only group size \& } \\
\text { sighting distance }\end{array}$ \\
\hline 40 & 25.12 .2006 & 28.12 .2006 & 741 & 24 & 47 & 1072 & 252 & 11,167 & 40.64 & 48.33 & 5,089 & 24,504 & 3,773 & 38.02 & 73.21 & 1814 & 7848 & \\
\hline 41 & 28.01 .2007 & 30.01 .2007 & $\sim 350$ & 8 & 3 & 312 & 65 & & & & & & & & & & & $\begin{array}{l}\text { only group size \& } \\
\text { sighting distance }\end{array}$ \\
\hline 42 & 23.02.2007 & 26.02.2007 & 824 & 22 & 24 & 636 & 509 & 5,581 & 62.92 & 51.26 & 1,751 & 17,791 & 6,856 & 36.02 & 63.06 & 3411 & 13779 & \\
\hline 43 & 23.02 .2007 & 25.02 .2007 & $\sim 350$ & 15 & 35 & 163 & 307 & & & & & & & & & & & $\begin{array}{l}\text { only group size \& } \\
\text { sighting distance }\end{array}$ \\
\hline 44 & 22.04 .2007 & 25.04 .2007 & 749 & 27 & 90 & 984 & 573 & 10,145 & 58.99 & 66.05 & 3,407 & 30,207 & 7,130 & 18.99 & 88.09 & 4906 & 10365 & \\
\hline 45 & 15.05 .2007 & 16.05 .2007 & $\sim 350$ & 8 & 44 & 110 & 227 & & & & & & & & & & & $\begin{array}{l}\text { only group size \& } \\
\text { sighting distance }\end{array}$ \\
\hline 46 & 17.06.2007 & 21.06 .2007 & 830 & 53 & 97 & 2466 & 394 & 22,926 & 44.55 & 95.74 & 9,851 & 53,354 & 3,041 & 20.49 & 65.51 & 2028 & 4559 & \\
\hline 47 & 16.07 .2007 & 18.07.2007 & $\sim 350$ & 30 & 30 & 1057 & 130 & & & & & & & & & & & $\begin{array}{c}\text { only group size \& } \\
\text { sighting distance }\end{array}$ \\
\hline 48 & 14.08.2007 & 16.08 .2007 & $\sim 762$ & 82 & 70 & 706 & 367 & & & & & & & & & & & $\begin{array}{c}\text { only group size \& } \\
\text { sighting distance - } \\
\text { track lost }\end{array}$ \\
\hline 49 & 28.10 .2007 & 31.10 .2007 & $\sim 762$ & 19 & 12 & 265 & 137 & & & & & & & & & & & $\begin{array}{l}\text { only group size \& } \\
\text { sighting distance - } \\
\text { track lost }\end{array}$ \\
\hline 50 & 27.11 .2007 & 28.11 .2007 & $\sim 350$ & 3 & 5 & 32 & 34 & & & & & & & & & & & $\begin{array}{l}\text { only group size \& } \\
\text { sighting distance }\end{array}$ \\
\hline
\end{tabular}




\begin{tabular}{|c|c|c|c|c|c|c|c|c|c|c|c|c|c|c|c|c|c|c|}
\hline \multirow{3}{*}{$\begin{array}{l}\# \\
51\end{array}$} & \multicolumn{2}{|c|}{ Date } & \multirow{3}{*}{$\begin{array}{c}\begin{array}{c}\text { Total effort } \\
\text { (in km) }\end{array} \\
724\end{array}$} & \multicolumn{2}{|c|}{ Groups encountered } & \multicolumn{2}{|c|}{ Total number seen } & \multicolumn{5}{|c|}{ DISTANCE estimate khulan } & \multicolumn{5}{|c|}{ DISTANCE estimate gazelle } & \multirow{3}{*}{ Comments } \\
\hline & \multirow{2}{*}{$\begin{array}{c}\text { from } \\
24.12 .2007\end{array}$} & \multirow{2}{*}{$\begin{array}{c}\text { to } \\
27.12 .2007\end{array}$} & & \multirow{2}{*}{$\begin{array}{c}\text { khulan } \\
8\end{array}$} & \multirow{2}{*}{$\frac{\text { gazelle }}{23}$} & \multirow{2}{*}{$\begin{array}{c}\text { khulan } \\
445\end{array}$} & \multirow{2}{*}{$\begin{array}{c}\text { gazelle } \\
193\end{array}$} & \multirow{2}{*}{ 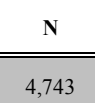 } & \multirow{2}{*}{$\begin{array}{c}\text { \%CV } \\
88.9\end{array}$} & \multirow{2}{*}{$\frac{\text { df }}{12.86}$} & \multicolumn{2}{|c|}{$95 \%$ CI } & \multirow{2}{*}{$\frac{\mathbf{N}}{2,957}$} & \multirow{2}{*}{ 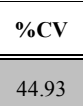 } & \multirow{2}{*}{ 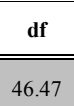 } & \multicolumn{2}{|c|}{$95 \% \mathrm{CI}$} & \\
\hline & & & & & & & & & & & 911 & 24,709 & & & & 1248 & 7009 & \\
\hline 52 & 26.01.2008 & 28.01 .2008 & $\sim 350$ & 1 & 5 & 10 & 66 & & & & & & & & & & & $\begin{array}{l}\text { only group size \& } \\
\text { sighting distance - } \\
\text { track lost }\end{array}$ \\
\hline 53 & 17.02 .2008 & 19.02 .2008 & $\sim 762$ & 19 & 24 & 1620 & 176 & & & & & & & & & & & $\begin{array}{l}\text { only group size \& } \\
\text { sighting distance - } \\
\text { all GPS data lost }\end{array}$ \\
\hline 54 & 28.03 .2008 & 29.03 .2008 & $\sim 350$ & 8 & 36 & 158 & 378 & & & & & & & & & & & $\begin{array}{l}\text { only group size \& } \\
\text { sighting distance }\end{array}$ \\
\hline 55 & 16.04 .2008 & 18.04 .2008 & 749 & 18 & 77 & 1046 & 485 & 10,777 & 56.21 & 48.62 & 3,759 & 30,896 & 6,034 & 20.03 & 88.9 & 4069 & 8949 & \\
\hline 56 & 24.05 .2008 & 25.05 .2008 & $\sim 350$ & 22 & 56 & 823 & 285 & & & & & & & & & & & $\begin{array}{c}\text { only group size \& } \\
\text { sighting distance }\end{array}$ \\
\hline 57 & 12.06.2008 & 13.06.2008 & 718 & 27 & 71 & 408 & 266 & 2,112 & 46.1 & 51.75 & 875 & 5,097 & 4,110 & 27.71 & 96.01 & 2395 & 7052 & \\
\hline 58 & 19.07.2008 & 20.07 .2008 & $\sim 350$ & 10 & 45 & 42 & 284 & & & & & & & & & & & $\begin{array}{l}\text { only group size \& } \\
\text { sighting distance }\end{array}$ \\
\hline 59 & 15.08.2008 & 18.08 .2008 & 714 & 39 & 66 & 4096 & 426 & 24,193 & 63.78 & 65.6 & 7,534 & 77,687 & 5,757 & 29.46 & 55.21 & 3229 & 10264 & \\
\hline 60 & 08.09.2008 & 09.09.2008 & $\sim 350$ & 16 & 38 & 3222 & 533 & & & & & & & & & & & $\begin{array}{c}\text { only group size \& } \\
\text { sighting distance }\end{array}$ \\
\hline 61 & 24.11 .2008 & 26.11 .2008 & 746 & 15 & 46 & 964 & 576 & 9,979 & 49.76 & 38.73 & 3,853 & 25,844 & 8,571 & 40.75 & 73.92 & 3925 & 18714 & \\
\hline 62 & 05.12 .2008 & 07.12 .2008 & 610 & 11 & 26 & 311 & 141 & 1,707 & 68.44 & 20.19 & 469 & 6,214 & 2,564 & 40.71 & 41.61 & 1163 & 5652 & \\
\hline 63 & 23.04.2009 & 25.04 .2009 & 711 & 32 & 65 & 586 & 516 & 6,361 & 44.53 & 70.1 & 2,724 & 14,856 & 8,051 & 33.23 & 73.05 & 4224 & 15346 & \\
\hline 64 & 13.05 .2009 & 15.05 .2009 & 744 & 34 & 89 & 697 & 673 & 7,235 & 47.66 & 65.51 & 2,932 & 17,857 & 9,235 & 27.03 & 67.48 & 5436 & 15691 & \\
\hline 65 & 11.06 .2009 & 13.06.2009 & 663 & 33 & 69 & 898 & 240 & 2,537 & 40.26 & 61.99 & 1,169 & 5,506 & 4,017 & 21.15 & 65.3 & 2645 & 6100 & \\
\hline 66 & 27.07.2009 & 30.07 .2009 & 735 & 27 & 133 & 463 & 694 & 4,850 & 39.33 & 62.64 & 2,273 & 10,350 & 8,798 & 20.68 & 59.02 & 5842 & 13249 & \\
\hline 67 & 06.08 .2009 & 08.08 .2009 & 784 & 33 & 86 & 4577 & 682 & 45,040 & 61.9 & 42.22 & 14,272 & 142,140 & 8,264 & 24.18 & 54.79 & 5125 & 13326 & \\
\hline 68 & 11.09 .2009 & 14.09 .2009 & 703 & 28 & 75 & 1063 & 539 & 11,675 & 53.15 & 46.43 & 4,279 & 31,854 & 8,509 & 23.48 & 65.04 & 5357 & 13517 & \\
\hline 69 & 20.10 .2009 & 23.10 .2009 & 566 & 24 & 50 & 622 & 549 & 8,486 & 63.45 & 44.96 & 2,630 & 27,383 & 10,766 & 29.29 & 53.87 & 6056 & 19138 & \\
\hline 70 & 12.08 .2010 & 14.08 .2010 & 750 & 56 & 65 & 1819 & 319 & 18,716 & 61.01 & 74.77 & 6,103 & 57,396 & 4,718 & 28.31 & 48.61 & 2700 & 8244 & \\
\hline 71 & 28.10 .2010 & 31.10 .2010 & 882 & 27 & 33 & 757 & 253 & 3,316 & 49.12 & 53.77 & 1,306 & 8,424 & 2,825 & 32.21 & 68.56 & 1509 & 5287 & \\
\hline All & 30.04 .2003 & 31.10 .2010 & $\sim 39,672$ & 2,197 & 3,778 & 71,405 & 22,029 & & & & & & & & & & & \\
\hline
\end{tabular}




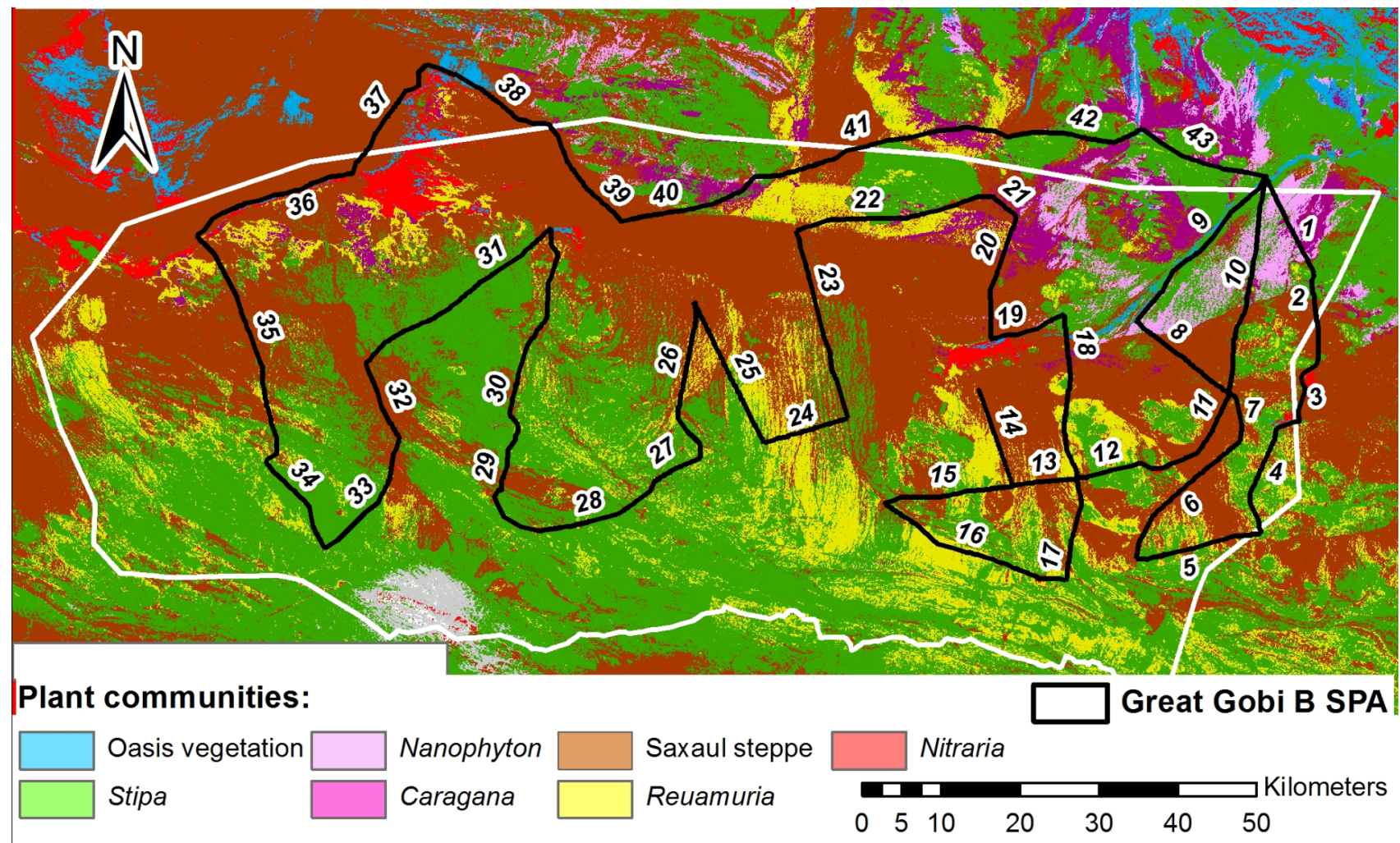

Appendix 3. Standard all park survey track consisting of 43 transects covering a total of $762 \mathrm{~km}$.

Appendix 4. Percentage of main behaviour of the khulans and goitered gazelles observed during 71 line transect surveys in Great Gobi B SPA from 2003-2010.

\begin{tabular}{|c|c|c|c|c|}
\hline \multirow{2}{*}{ Species } & \multicolumn{4}{|c|}{ Main Behaviour of Animal / Group of Animals } \\
\cline { 2 - 5 } & Laying & Standing & Walking & 5 \\
\hline \hline Gazelle & 13 & 10 & 5 & 71 \\
\hline Khulan & 22 & 16 & 57 \\
\hline
\end{tabular}

Appendix 5. Proportion of young of the year in groups containing foals or fawns in Great Gobi B SPA from 2003-2010.

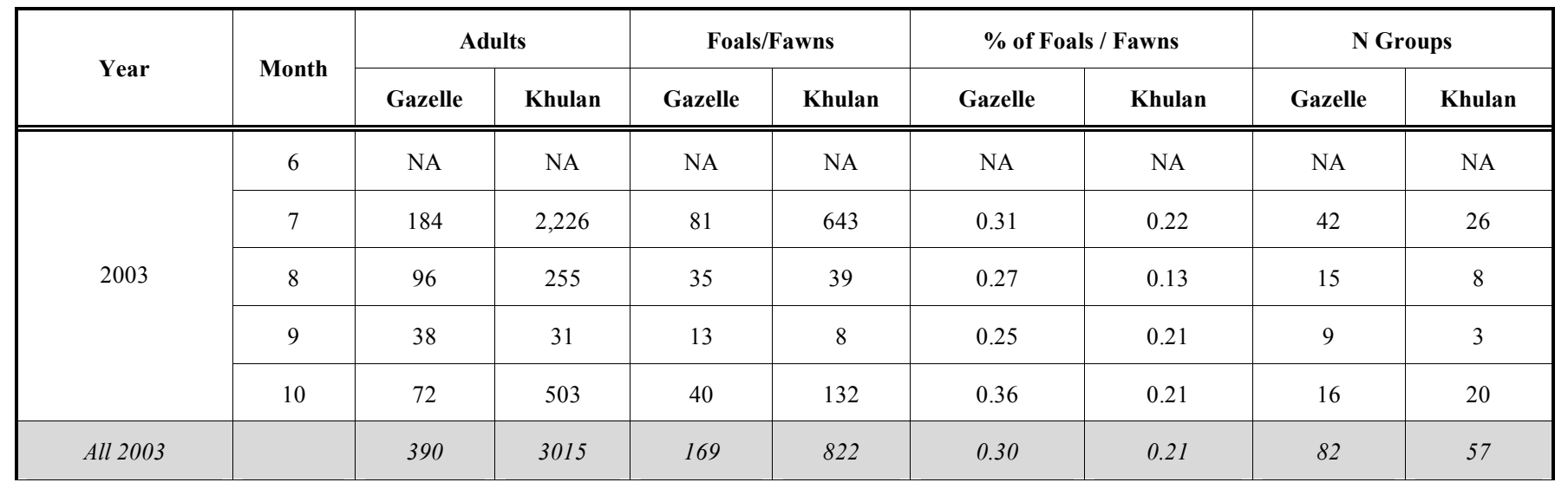


Appendix 5. Contd...

\begin{tabular}{|c|c|c|c|c|c|c|c|c|c|}
\hline \multirow{2}{*}{ Year } & \multirow{2}{*}{ Month } & \multicolumn{2}{|c|}{ Adults } & \multicolumn{2}{|c|}{ Foals/Fawns } & \multicolumn{2}{|c|}{$\%$ of Foals / Fawns } & \multicolumn{2}{|c|}{ N Groups } \\
\hline & & Gazelle & Khulan & Gazelle & Khulan & Gazelle & Khulan & Gazelle & Khulan \\
\hline \multirow{5}{*}{2004} & 6 & 2 & 112 & 1 & 6 & 0.33 & 0.05 & 1 & 5 \\
\hline & 7 & 99 & 14 & 61 & 7 & 0.38 & 0.33 & 28 & 4 \\
\hline & 8 & 110 & 296 & 82 & 108 & 0.43 & 0.27 & 36 & 15 \\
\hline & 9 & 31 & 927 & 16 & 321 & 0.34 & 0.26 & 9 & 11 \\
\hline & 10 & 242 & 246 & 108 & 56 & 0.31 & 0.19 & 37 & 15 \\
\hline All 2004 & & 482 & 1483 & 267 & 492 & 0.36 & 0.25 & 110 & 45 \\
\hline \multirow{5}{*}{2005} & 6 & --- & 642 & --- & 56 & --- & 0.08 & 0 & 6 \\
\hline & 7 & 91 & 125 & 46 & 50 & 0.34 & 0.29 & 18 & 11 \\
\hline & 8 & 164 & 283 & 56 & 50 & 0.25 & 0.15 & 24 & 13 \\
\hline & 9 & 33 & --- & 18 & --- & --- & --- & 7 & 0 \\
\hline & 10 & 96 & 30 & 30 & 9 & 0.24 & 0.23 & 5 & 4 \\
\hline All 2005 & & 384 & 438 & 150 & 109 & 0.28 & 0.20 & 54 & 28 \\
\hline \multirow{5}{*}{2006} & 6 & 30 & 307 & 16 & 22 & 0.35 & 0.07 & 10 & 9 \\
\hline & 7 & 57 & 1,382 & 54 & 383 & 0.49 & 0.22 & 26 & 19 \\
\hline & 8 & 191 & 228 & 133 & 96 & 0.41 & 0.30 & 54 & 12 \\
\hline & 9 & 11 & 43 & 8 & 22 & 0.42 & 0.34 & 5 & 4 \\
\hline & 10 & 75 & 340 & 51 & 125 & 0.40 & 0.27 & 27 & 14 \\
\hline All 2006 & & 334 & 1993 & 246 & 626 & 0.42 & 0.24 & 112 & 49 \\
\hline \multirow{5}{*}{2007} & 6 & 112 & 2,142 & 42 & 234 & 0.27 & 0.10 & 18 & 21 \\
\hline & 7 & 58 & 43 & 35 & 8 & 0.38 & 0.16 & 13 & 3 \\
\hline & 8 & 164 & 133 & 81 & 35 & 0.33 & 0.21 & 39 & 15 \\
\hline & 9 & NA & NA & NA & NA & NA & NA & NA & NA \\
\hline & 10 & 70 & 192 & 10 & 37 & 0.13 & 0.16 & 4 & 9 \\
\hline All 2007 & & 292 & 368 & 126 & 80 & 0.30 & 0.18 & 56 & 27 \\
\hline \multirow{5}{*}{2008} & 6 & 51 & 20 & 5 & 3 & 0.09 & 0.13 & 3 & 3 \\
\hline & 7 & 24 & --- & 6 & --- & --- & --- & 3 & 0 \\
\hline & 8 & 79 & 1,278 & 31 & 260 & 0.28 & 0.17 & 17 & 5 \\
\hline & 9 & 160 & 2,523 & 53 & 643 & 0.25 & 0.20 & 6 & 11 \\
\hline & 10 & NA & NA & NA & NA & NA & NA & NA & NA \\
\hline All 2008 & & 263 & 3801 & 90 & 903 & 0.25 & 0.19 & 26 & 16 \\
\hline
\end{tabular}


Appendix 5. Contd...

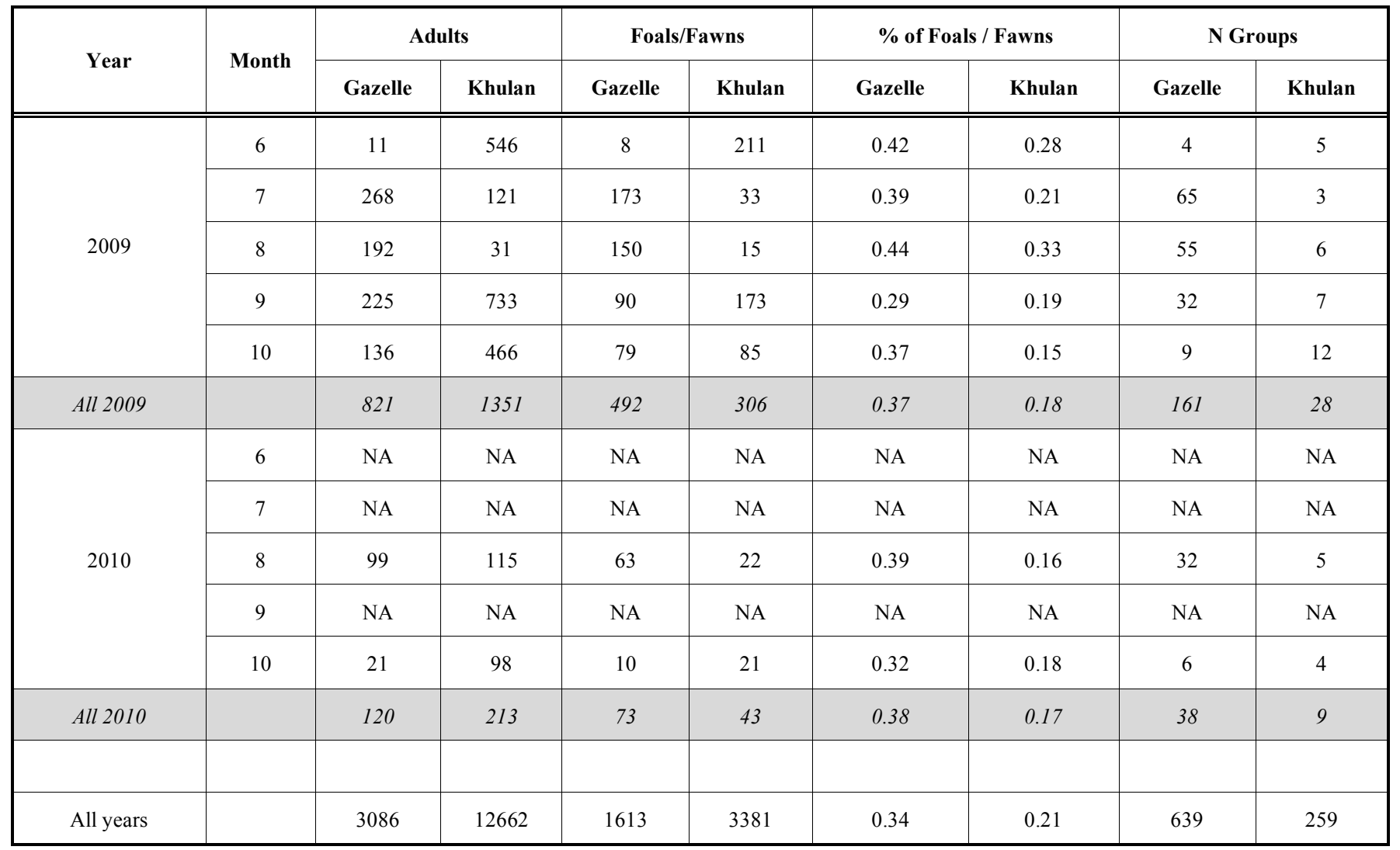

Appendix 6. Observations of very large groups of khulans and large groups of gazelles in Great Gobi B SPA from $2003-2010$.

\begin{tabular}{|c|c|c|c|c|c|}
\hline \multicolumn{3}{|c|}{ Khulan } & \multicolumn{3}{|c|}{ Gazelle } \\
\hline Date & Season & Group size & Date & Season & Group Size \\
\hline 01.07 .2003 & summer & 850 & 25.03 .2004 & spring & 60 \\
\hline 06.07 .2003 & summer & 802 & 19.10 .2004 & fall & 64 \\
\hline 08.07 .2003 & summer & 735 & 22.03 .2006 & spring & 78 \\
\hline 18.04 .2004 & spring & 634 & 23.02 .2007 & winter & 73 \\
\hline 07.09 .2004 & fall & 900 & 24.02 .2007 & winter & 73 \\
\hline 16.10 .2004 & fall & 600 & 23.04 .2007 & spring & 100 \\
\hline 11.06 .2005 & summer & 650 & 26.11 .2008 & fall & 111 \\
\hline 11.06 .2005 & summer & 1,000 & 26.11 .2008 & fall & 75 \\
\hline 19.06 .2007 & summer & 600 & 26.11 .2008 & fall & 62 \\
\hline 15.08 .2008 & summer & 1,200 & 24.04 .2009 & spring & 81 \\
\hline 15.08 .2008 & summer & 1,200 & 14.05 .2009 & spring & 66 \\
\hline 11.06 .2009 & summer & 700 & 23.10 .2009 & fall & 60 \\
\hline 07.08.2009 & summer & 2,110 & & & \\
\hline 07.08.2009 & summer & 1,500 & & & \\
\hline 07.08 .2009 & summer & 800 & & & \\
\hline 13.08 .2010 & summer & 1,000 & & & \\
\hline
\end{tabular}




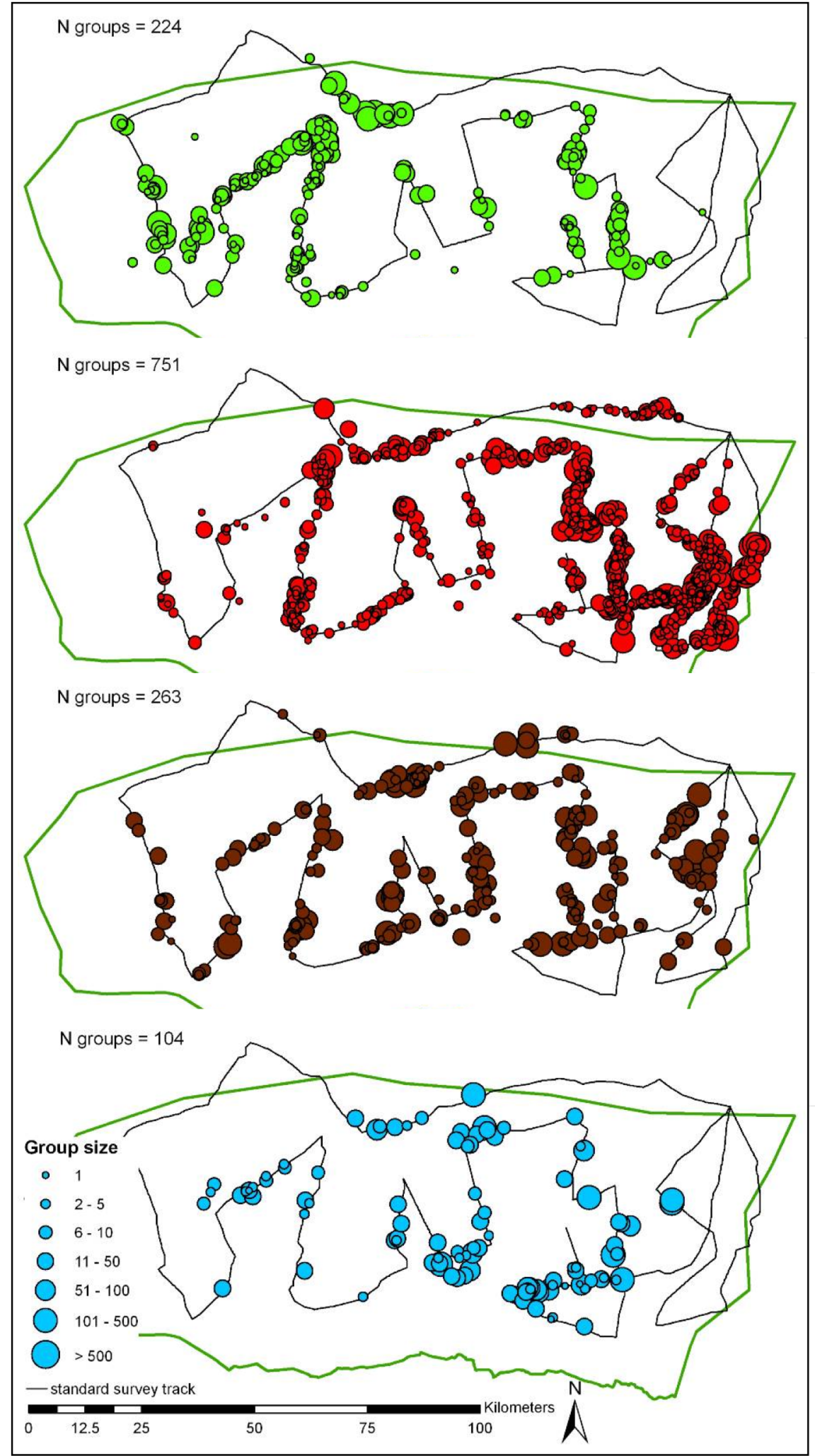

A) Seasonal distribution of all wild ass observations in Great Gobi B SPA from 2003-2010.

Appendix 7. contd... 


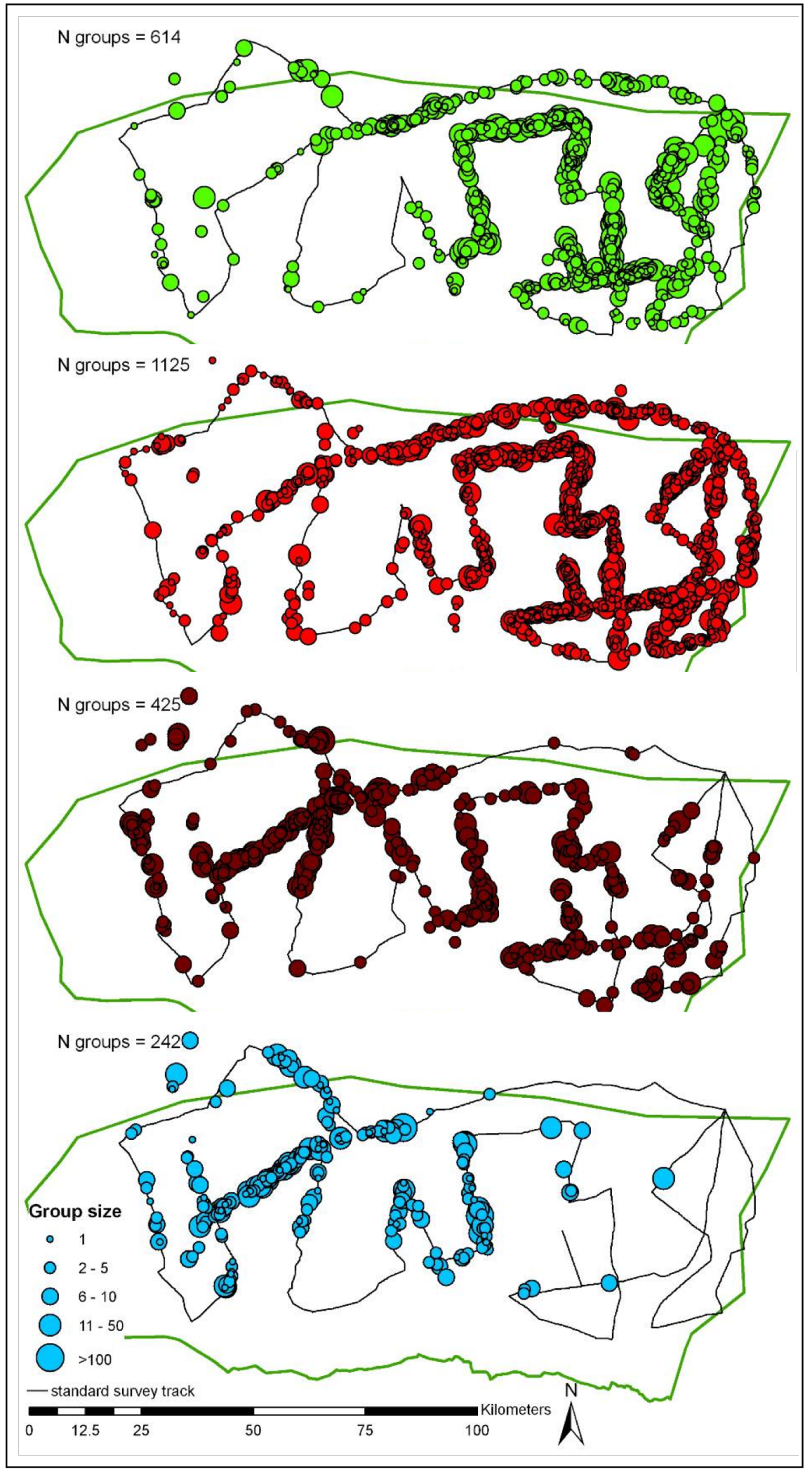

B) Seasonal distribution of all gazelle observations in Great Gobi B SPA from 2003-2010.

Appendix 7: 


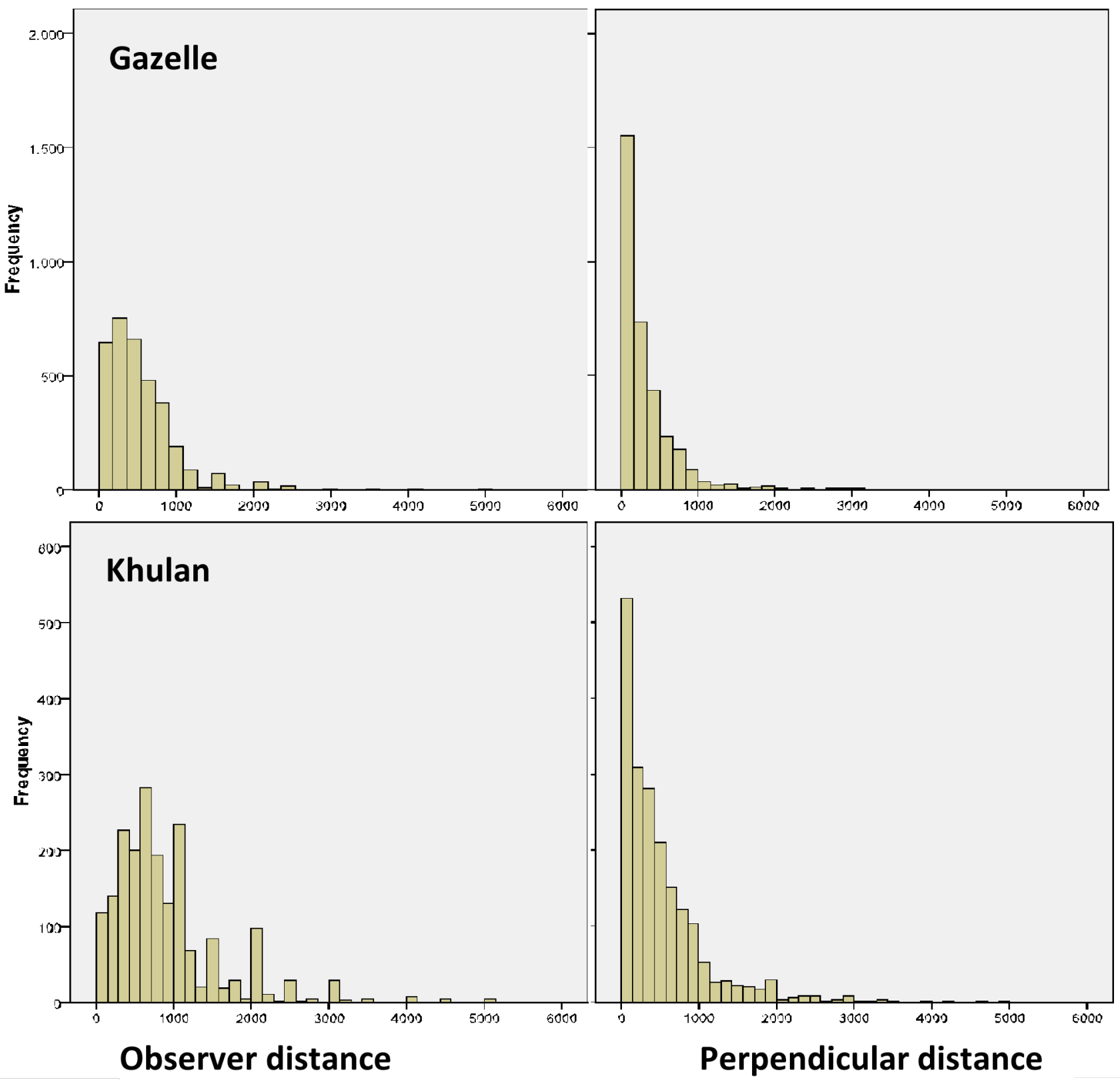

Appendix 8. Observer and perpendicular distances in goitered gazelles and khulans in Great Gobi B SPA from 2003-2010.

\section{REFERENCES}

Amgalan, L (2000) Conservation and Bio-ecological Peculliarities of Goitered Gazelle (Gazella Subgutturosa), PhD Dissertation, National University of Mongolia, Mongolia.

Asa, CS (2002). Equid Reproductive Biology. In: Moehlman, P (Ed.) Equids: Zebras, Asses and Horses, IUCN Publication Services Unit, Cambridge, UK

Bårdsen, BJ \& Fox, JL (2006). Evaluation of line transect sampling for density estimates of chiru Pantholops hodgsoni in the Aru Basin Tibet. Wildlife Biology, 12, 89-100.

Batsaikhan, N, Buuveibaatar, B, Chimed, B, Enkhtuya, O, Galbrakh, D, Ganbaatar, O, Lhagvasuren, B, Nandintsetseg, D, Berger, J, Calabrese, JM, Edwards, AE, Fagan, WF, Fuller, TK, Heiner, M, Ito, TY, Kaczensky, P, Leimgruber, P, Lushchekina, A, MilnerGulland, EJ, Mueller, T, Murray, MG, Olson, KA, Reading, R, Schaller, GB, Stubbe, A, Stubbe, M, Walzer, C, von, HW \& Whitten, T (2014). Conserving the World's Finest Grassland Amidst Ambitious National Development. Conservation Biology, 28, 1736-
Berger, J, Buuveibaatar, B, \& Mishra, C (2013). Globalization of the cashmere market and the decline of large mammals in central asia. Conservation Biology, 27, 679-89

Blank, DA (1998) Mating behavior of the Persian Gazelle Gazella subgutturosa Guldenstaedt, 1780. Mammalia, 62, 499-19.

Blank, D, Ruckstuhl, K, \& Yang, W (2012). Influence of population density on group sizes in goitered gazelle (Gazella subgutturosa Guld., 1780). European Journal of Wildlife Research, 58, 981-89.

Buckland, ST, Anderson, DR, Burnham, KP, Laake, JL, Borchers, DL \& Thomas, L (2001). Introduction to Distance Sampling, Oxford University Press., UK.

Durant, SM, Craft, ME, Hilborn, R, Bashir, S, Hando, J \& Thomas, L (2011). Long-term trends in carnivore abundance using distance sampling in Serengeti National Park. Tanzania, Journal of Applied Ecology, 48, 1490-1500

Enkhbileg, D, Mijiddorj, B, \& Adiya, Y (2007). Current status of the khulan (Equus hemionus) in the Trans-Altai Gobi. Exploration into the Biological Resources of Mongolia (Halle/Saale), 10, 49-60. 
Feh, C, Munkhtuya, B, Enkhbold, S \& Sukhbaatar, T (2001). Ecology and social structure of the Gobi khulan Equus hemionus subsp. in the Gobi B National Park, Mongolia. Biological Conservation, 101, 51-61.

Fernandez-Gimenez, ME (1999) Sustaining the Steppes: a geographical history of pastoral land use in Mongolia. Geographical Review, 89, 315-42.

Fernandez-Gimenez, ME \& Allen-Diaz B (1999). Testing a non-equilibrium model of rangeland vegetation dynamics in Mongolia. Journal of Applied Ecology, 36, 871-85.

Harris, RB (1996) Wild Ungulate surveys in grassland habitats: satisfying methodological assumptions. Chinese Journal of Zoology, 31, 1621.

Hastie, T \& Tibshirani, R (1990). Generalized Additive Models. Chapman and Hall, London.

Heptner, VG, Nasimovich, AA \& Bannikov, AG (1988). Mammals of the Soviet Union Volume 1 - Artiodactyla and Perissodactyla. Pages 609-634 Goitered gazelle: Gazella subgutturosa. English translation of the original book published in 1961 by Vysshaya Shkola Publishers Moscow. Smithsonian Institution Libraries and The National Science Foundation Washington, D.C., USA.

IPCC (2007) Climate Change 2007: Impacts, Adaptation and Vulnerability. Parry, M, Canziani, O, Palutikof, J, van der, PL \& Hanson, C (Eds.) Contribution of Working Group II to the Fourth Assessment Report of the Inter-governmental Panel on Climate Change. Cambridge University Press, Cambridge.

Johnson, JB, \& Omland, KS (2004). Model selection in ecology and evolution. Trends in Ecology \& Evolution, 19, 101-08.

Kaczensky, P, Sheehy, DP, Johnson, DE, Walzer, C, Lhkagvasuren, D, Sheehy, CM (2006) Room to roam? The threat to khulan (Wild Ass) from human intrusion. Mongolia Discussion Papers. East Asia and Pacific Environment and Social Development Departure. WorldBank, Washington, D.C., USA.

Kaczensky, P, Enkhsaikhan, N, Ganbaatar, O \& Walzer, C (2007a). Identification of herder-wild equid conflicts in the Great Gobi B Strictly Protected Area in SOUTH-WESTERN Mongolia. Exploration into the Biological Resources of Mongolia (Halle/Saale), 10, 99-116.

Kaczensky, P, Ganbaatar, O, Von-Wehrden H, Enksaikhan, N, Lkhagvasuren, D \& Walzer, C (2007) Przewalski horse re-introduction in the Great Gobi B SPA - from species to ecosystem conservation. Mongolian Journal of Biological Sciences, 5, 13-18.

Kaczensky, P, Ganbaatar, O, Von-Wehrden, H \& Walzer, C (2008). Resource selection by sympatric wild equids in the Mongolian Gobi. Journal of Applied Ecology, 45, 1762-9.

Kaczensky, P, Kuehn, R, Lhagvasuren, B, Pietsch, S, Yang, W \& Walzer, C (2011). Connectivity of the Asiatic wild ass population in the Mongolian Gobi. Biological Conservation, 144, 920-9.

Kaczensky, P, Ganbataar, O, Altansukh, N, Enkhsaikhan, N, Stauffer, C \& Walzer, C (2011). The danger of having all your eggs in one basket - winter crash of the re-introduced przewalski's horses in the mongolian. PloS ONE, 6(12), e28057.

Kaczensky, P, Ransom, J, Ganbaatar, O \& Altansukh, N (2012). Simultanious ground count of the Asiatic wild ass in the Great Gobi B Strictly Protected Area. Equus, 7, 6-15.

Kéry, M, Dorazio, RM, Soldaat, L, Van-Strien, A, Zuiderwijk, A \& Royle, JA (2009). Trend estimation in populations with imperfect detection. Journal of Applied Ecology, 46, 1163-72.

Lhagvasuren, B, Dulamtseren, S, Amgalan, L, Mallon, D, Schaller, G, Reading, RP \& Mix, H (1999) Status and conservation of Antelopes in Mongolia. Proceedings of the Institute of Biology of the Mongolian Academy of Sciences, 1, 96-107.

Lhagvasuren, B (2007). Population assessment of khulan (Equus hemionus) in Mongolia. Exploration into the Biological Resources of Mongolia (Halle/Saale), 10, 45-8.

Mallon, DP (2008). Gazella subgutturosa. In: IUCN 2010. IUCN Red List of Threatened Species. Version 2010.4 (available from http//www.iucnredlist.org, Accessed 20 October, 2013

Mallon, DP \& Jiang, Z, (2009). Grazers on the plains: challenges and prospects for large herbivores in central Asia. Journal of Applied Ecology, 46, 516-9.

McConville, AJ, Grachev, IuA, Keane, A, Coulson, T, Bekenov, AB \& Milner-Gulland, EJ (2009) Reconstructing the observation process to correct for changing detection probability of a critically endangered species. Endangered Species Research, 6, 231-7.
Moehlman, PD, Shah, N \& Feh, C (2008) Equus hemionus. In: IUCN 2011. IUCN Red List of Threatened Species. Version 2011.1. (available from http//www.iucnredlist.org, Accessed 20 October 2013

Moore, JE \& Barlow, J (2011) Bayesian state-space model of fin whale abundance trends from a 1991-2008 time series of line-transect surveys in the California Current. Journal of Applied Ecology, 48, 1195-1205.

Norton-Griffiths, M, Frederick, H, Slaymaker, DM \& Payne, J (2013). Preliminary estimates of wildlife and livestock populations in the Oyu Tolgoi Area of the south-eastern Gobi Desert, Mongolia, May July 2013. Unpublished preliminary report to Oyu Tolgoi, Mongolia.

Pratt, DG, MacMillan, DC \& Gordon, IJ (2004). Local community attitudes to wildlife utilisation in the changing economic and social context of Mongolia. Biodiversity and Conservation, 13, 591-613.

Qiao, J, Yang, W, Xu, W, Xia, C, Liu, W \& Blank, D (2011) Social Structure of Goitered gazelles Gazella subgutturosa in Xinjiang, China. Pakistan Journal of Zoology, 43, 769-75.

Ransom, JI (2011). Customizing a rangefinder for community-based large animal surveys. Biodiversity and Conservation, 20, 1603-9.

Ransom, JI, Kaczensky, P, Lubow, BC, Ganbaatar, O \& Altansukh, N (2012). A collaborative approach for estimating terrestrial wildlife abundance. Biological Conservation, 153, 219-26.

Reading, RP, Mix, HM, Lhagvasuren, B, Feh, C, Kane, DP, Dulamtseren, S $\&$ Enkhbold, S (2001). Status and distribution of khulan (Equus hemionus). Journal of Zoology, 254, 381-9.

R Development Core Team (2009). R: A language and environment for statistical computing. R Foundation for Statistical Computing, Vienna, Austria (available from http://www.R-project.org), [Accessed 5 January 2012].

Robinson, S \& Milner-Gulland, EJ (2003). Political Change and Factors Limiting Numbers of wild and domestic ungulates in Kazakhstan. Human Ecology, 31, 87-110.

Rodrigues, AS, Pilgrim, JD, Lamoreux, JF, Hoffmann, M \& Brooks, TM (2006) The value of the IUCN Red List for conservation. Trends in Ecology and Evolution, 21, 71-6.

Schaller, GB (1998). Wildlife of the Tibetan steppe. University of Chicago Press, Chicago.

Schook, MW, Wildt, DE, Weiss, RB, Wolfe, BA, Archibald, KE \& Pukazhenthi, BS (2013). Fundamental studies of the reproductive biology of the endangered Persian onager (Equus hemionus onager) result in first wild equid offspring from artificial insemination. Biology of Reproduction, 89, 41.

Sheehy, DP, Sheehy, CM, Johnson, DE, Damiran, D \& Fiemengo, M (2010). Livestock and Wildlife in the Southern Gobi Region, with Special Attention to Wild As Mongolia Discussion Papers East Asia and Pacific Sustainable Development Department. World Bank, Washington, D.C.

Singh, NJ \& Milner-Gulland, EJ (2011). Monitoring ungulates in Central Asia: current constraints and future potential. Oryx, 45(1), 38-49.

Sutherland, WJ (2006) Ecological Census Techniques, $2^{\text {nd }}$ ed. Cambridge University Press, Cambridge.

Sundaresan, SR, Fischhoff, IR, Dushoff, J \& Rubenstein, DI (2007). Network metrics reveal differences in social organization between fission-fusion species Grevy's zebra and onager. Oecologia, 151, 1409 .

Thomas, L, Buckland, ST, Rexstad, EA, Laake, JL, Strindberg, S, Hedley, SL, Bishop, JRB, Marques, TA \& Burnham, KP (2010). Distance software: design and analysis of distance sampling surveys for estimating population size. Journal of Applied Ecology, 47, 5-14.

Von-Wehrden, H, Wesche, K \& Tungalag, R (2006) Plant communities of the Great Gobi B Strictly Protected Area. Mongolian Journal of Biological Sciences, 4, 3-17.

Tsendjav, D \& Purevsuren, S (2007). Some information on the ecology of the khulan (Equus hemionus Pallas 1775 in the western part of the South Gobi province Mongolia. Exploration into the Biological Resources of Mongolia (Halle/Saale), 10, 61-8.

Vander-Wal E, Van-Beest, FM \& Brook, RK (2013) Density-Dependent Effects on Group Size Are Sex-Specific in a Gregarious Ungulate. PLoS ONE, 8(1), e53777.

Wingard, JR \& Zahler, P (2006). Silent Steppe: The illegal Wildlife Trade Crisis. Mongolia Discussion Papers, East Asia and Pacific Environment and Social Development Department. World Bank, Washington, D.C. 
Xia, C, Liu, W, Xu, W, Yang, W, Xu, F \& Blank, D (2014). The energymaintenance strategy of goitered gazelles Gazella subgutturosa during rut. Behavioural Processes, 103, 5-8.

Xu, W, Xia, C, Lin, J, Yang, W, Blank, D, Qiao, J \& Liu, W (2012). Diet of Gazella subgutturosa (Güldenstaedt, 1780) and food overlap with domestic sheep in Xinjiang, China. Folia Zoologica, 61, 54-60.
Zhirnov, LV \& Ilyinsky, VO (1986). The Great Gobi National Park - a refuge for rare animals in the central Asian deserts. Centre for International Projects, GKNT, Moscow, Russia.

Zuur, AF, Ieno, EN, Walker, NJ, Savleiev, AA \& Smith, GM (2009). Mixed Effects Models and Extensions. Springer Science and Business Media, New York. USA.

Received: September 18, 2014

Revised: November 23, 2015

Accepted: November 24, 2015

(C) Kaczensky et al.; Licensee Bentham Open .

This is an open access article licensed under the terms of the Creative Commons Attribution Non-Commercial License (http://creativecommons.org/ licenses/by-nc/4.0/), which permits unrestricted, non-commercial use, distribution and reproduction in any medium, provided the work is properly cited. 